\title{
Differential coral bleaching-Contrasting the activity and response of enzymatic antioxidants in symbiotic partners under thermal stress
}

\author{
Thomas Krueger a,b,*, Thomas D. Hawkins a,c , Susanne Becker a, Stefanie Pontasch ${ }^{\text {a }}$, Sophie Dove ${ }^{\mathrm{d}}$, \\ Ove Hoegh-Guldberg ${ }^{\mathrm{e}}$, William Leggat ${ }^{\mathrm{f}}$, Paul L. Fisher ${ }^{\mathrm{a}, \mathrm{g}}$, Simon K. Davy ${ }^{\mathrm{a}, * *}$ \\ a School of Biological Sciences, Victoria University of Wellington, Wellington 6140, New Zealand \\ b Laboratory for Biological Geochemistry, School of Architecture, Civil and Environmental Engineering (ENAC), École Polytechnique Fédérale de Lausanne (EPFL), Lausanne 1015, Switzerland \\ c College of Earth, Ocean and Environment, University of Delaware, Lewes, DE 19958, USA \\ ' School of Biological Sciences E ARC Centre of Excellence for Coral Reef Studies, University of Queensland, Brisbane, QLD 4072, Australia \\ e Global Change Institute, University of University of Queensland, Brisbane, QLD 4072, Australia \\ ${ }^{\mathrm{f}}$ Comparative Genomics Centre, School of Pharmacy and Molecular Sciences E' ARC Centre of Excellence for Coral Reef Studies, James Cook University, Townsville, QLD 4811, Australia \\ ' School of Civil Engineering, University of Queensland, St Lucia, QLD 4072, Australia
}

\section{A R T I C L E I N F O}

Article history:

Received 22 April 2015

Received in revised form 13 August 2015

Accepted 19 August 2015

Available online 23 August 2015

\section{Keywords:}

APX

Acropora millepora

CAT

Global change

Montipora digitata

Oxidative stress

SOD

Symbiodinium

Symbiosis

Thermal biology

\begin{abstract}
A B S T R A C T
Mass coral bleaching due to thermal stress represents a major threat to the integrity and functioning of coral reefs. Thermal thresholds vary, however, between corals, partly as a result of the specific type of endosymbiotic dinoflagellate (Symbiodinium sp.) they harbour. The production of reactive oxygen species (ROS) in corals under thermal and light stress has been recognised as one mechanism that can lead to cellular damage and the loss of their symbiont population (Oxidative Theory of Coral Bleaching). Here, we compared the response of symbiont and host enzymatic antioxidants in the coral species Acropora millepora and Montipora digitata at $28{ }^{\circ} \mathrm{C}$ and $33^{\circ} \mathrm{C}$. A. millepora at $33^{\circ} \mathrm{C}$ showed a decrease in photochemical efficiency of photosystem II (PSII) and increase in maximum midday excitation pressure on PSII, with subsequent bleaching (declining photosynthetic pigment and symbiont density). M. digitata exhibited no bleaching response and photochemical changes in its symbionts were minor. The symbiont antioxidant enzymes superoxide dismutase, ascorbate peroxidase, and catalase peroxidase showed no significant upregulation to elevated temperatures in either coral, while only catalase was significantly elevated in both coral hosts at $33^{\circ} \mathrm{C}$. Increased host catalase activity in the susceptible coral after 5 days at $33^{\circ} \mathrm{C}$ was independent of antioxidant responses in the symbiont and preceded significant declines in PSII photochemical efficiencies. This finding suggests a potential decoupling of host redox mechanisms from symbiont photophysiology and raises questions about the importance of symbiont-derived ROS in initiating coral bleaching.
\end{abstract}

(c) 2015 Elsevier Inc. All rights reserved.

\section{Introduction}

Scleractinian corals are important ecosystem engineers building the three-dimensional coral reef framework that supports the immense biodiversity seen in tropical coastal waters. This ecological role is underpinned by the coral's endosymbiosis with dinoflagellates of the genus Symbiodinium, which supply carbon-rich photosynthates to the host coral, promote nitrogen recycling and conservation, and enhance

\footnotetext{
* Correspondence to: T. Krueger, Laboratory for Biological Geochemistry, School of Architecture, Civil and Environmental Engineering (ENAC), École Polytechnique Fédérale de Lausanne (EPFL), Lausanne 1015, Switzerland

** Corresponding author.

E-mail addresses: thomas.krueger@epfl.ch (T. Krueger), thawkins@udel.edu (T.D. Hawkins), susanne.becker25@gmail.com (S. Becker), steffipont@gmail.com (S. Pontasch), s.dove@cms.uq.edu.au (S. Dove), oveh@uq.edu.au (O. Hoegh-Guldberg), bill.leggat@jcu.edu.au (W. Leggat), p.fisher@uq.edu.au (P.L. Fisher), simon.davy@vuw.ac.nz (S.K. Davy).
}

rates of calcification (Muscatine and Porter, 1977). The relationship between the animal and its algal symbionts is therefore a major determinant of individual coral health and ultimately reef function. The disruption of this symbiosis by environmental stress and disease has been termed coral bleaching, since it is phenotypically visible as paling of the coral tissue as a result of a decline in symbiont photosynthetic pigment content and/or cell density (Iglesias-Prieto and Trench, 1994). With the onset of anthropogenic marine pollution and climate change, reef systems worldwide have experienced major perturbations and regime shifts, as well as bleaching events that have led to significant coral mortality (Pandolfi et al., 2003). Today, thermal bleaching triggered by ocean warming is one of the main global challenges facing reef systems.

Thermal stress thresholds and subsequent mortality vary between coral species in the reef community (Loya et al., 2001; Stimson et al., 2002). This differential bleaching susceptibility is, to a certain extent, a result of the specific holobiont composition, i.e. the combination of 
different host species and one or multiple Symbiodinium genotypes (Rowan et al., 1997; Abrego et al., 2008; Sampayo et al., 2008). In addition, physiological acclimation and repeated stress exposure (Iglesias-Prieto and Trench, 1994; Middlebrook et al., 2008; Grottoli et al., 2014), host genetic background (Smith-Keune and van Oppen, 2006; Barshis et al., 2010), symbiont effects on host physiology (Rowan, 2004; Ulstrup et al., 2007; Abrego et al., 2008), and host heterotrophy during episodes of bleaching and recovery (Grottoli et al., 2004; Grottoli et al., 2006), are important factors that define the stability and resilience of the coral symbiosis (Fig. 1). However, the relative importance of different symbionts to the holobiont's resilience is difficult to assess due to complex interactions and trade-offs (Fitt et al., 2001; Abrego et al., 2008; Fitt et al., 2009; Jones and Berkelmans, 2010). Moreover, while some intracellular sites and effects of thermal damage in the host and symbiont have been identified, there is no consensus about the causal chain of events and the supposed 'weak link' in the symbiosis. Indeed, bleaching can be manifested as host-cell detachment and/or release of potentially photosynthetically competent symbionts (Gates et al., 1992; Ralph et al., 2001), as well as breakdown of photosynthetic dark and light reactions (Jones et al., 1998; Warner et al., 1999), and apoptosis and necrosis in both partners (Dunn et al., 2004; Tchernov et al., 2011; Hawkins et al., 2013; Paxton et al., 2013).

One key process, first suggested by Lesser et al. (1990), is the leakage of reactive oxygen species (ROS) from the symbiont to the host, which then challenges and potentially overwhelms the host's antioxidant capacity under stressful conditions (Downs et al., 2002; Weis, 2008). In addition, high levels of ROS as well as reactive nitrogen species (RNS) in the host gastrodermal cell could stimulate innate immune-like pathways and potentially trigger pro-apoptotic processes in the host (Fig. 1, Perez and Weis, 2006; Dunn et al., 2007; Hawkins et al., 2013). The involvement of ROS in coral bleaching led to the proposal of a unifying mechanistic model of coral bleaching: the 'Oxidative Theory of Coral Bleaching' (OTB). This hypothesis proposes that exposure to temperature and light stress initiates the bleaching cascade primarily by compromising symbiont photosynthesis, leading to the excessive generation of ROS and RNS in the symbiont (reviewed in Weis, 2008). Potential ROS leakage into the host tissue in combination with damage and possible activation of apoptotic pathways in both partners results in the breakdown of the symbiotic relationship (reviewed in Weis, 2008; Lesser, 2011).

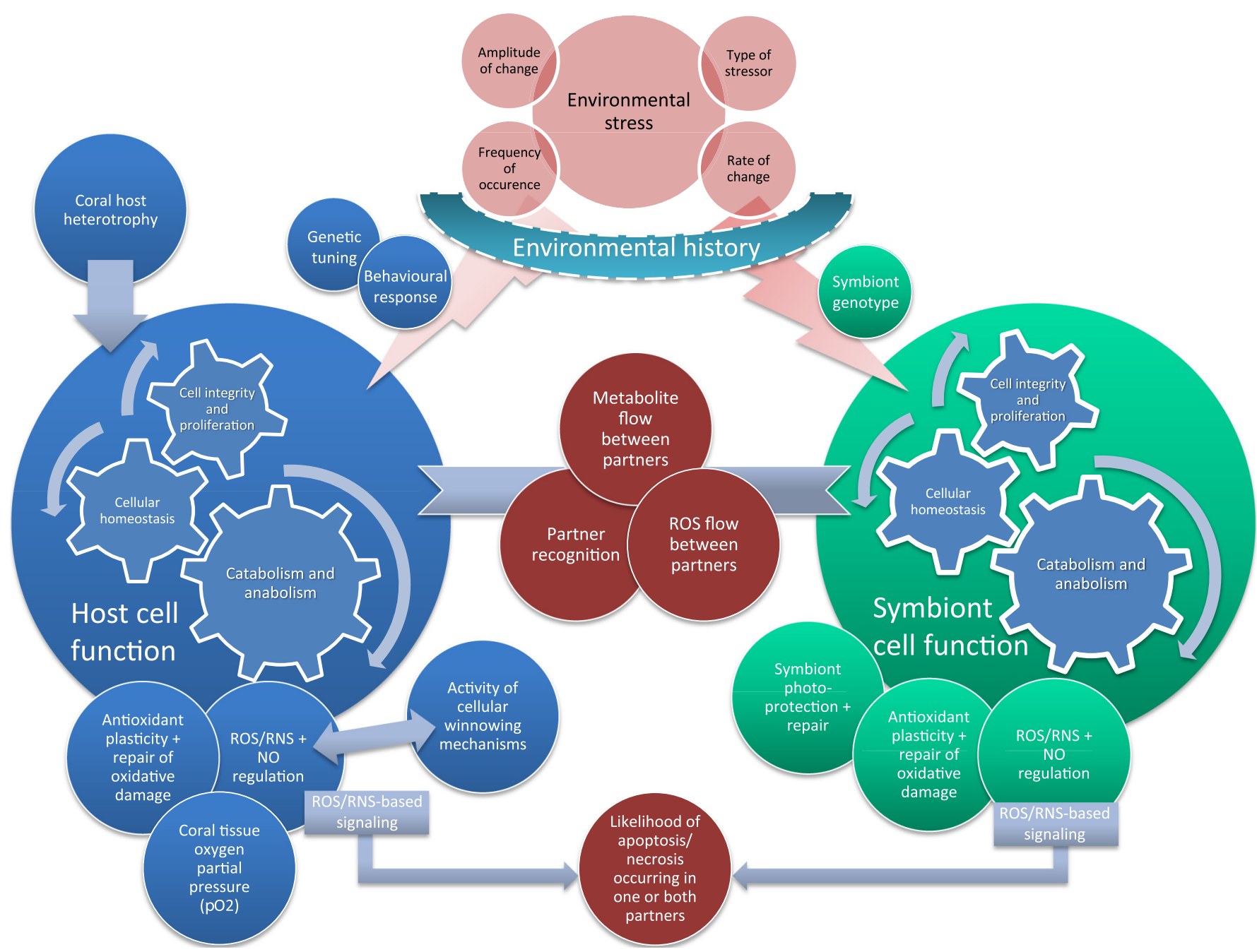

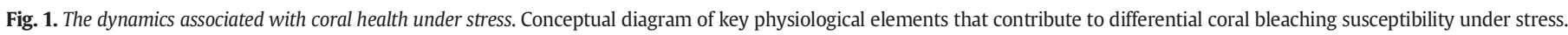

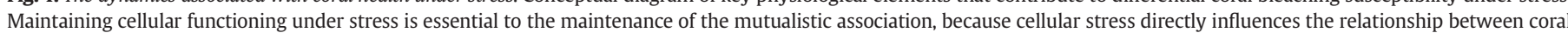

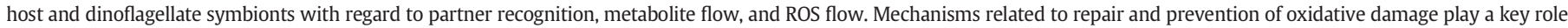

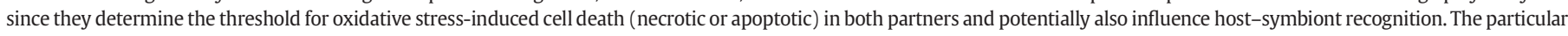

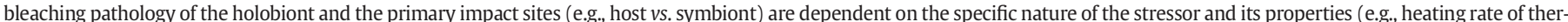

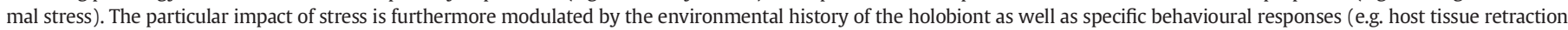

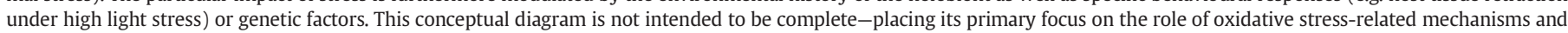
their connection to other physiological processes. ROS, reactive oxygen species; RNS reactive nitrogen species; NO nitric oxide. 
A large body of literature reports increased antioxidant activity or evidence for oxidative damage as a result of thermal and light stress in both the symbiont and host, supporting the idea that oxidative stress is the trigger of coral bleaching (reviewed by Lesser, 2006; Lesser, 2011). To what extent photoprotective mechanisms in the symbiont and antioxidant capacities in both partners contribute to the overall bleaching susceptibility of the holobiont is therefore an important question that needs to be answered if we are to understand the physiological basis of differential bleaching susceptibilities. In the context of the OTB, differential bleaching susceptibility between holobionts should be related to mechanisms that prevent or combat the excessive generation of ROS under thermal stress (Downs et al., 2002). The goal of this study was to contrast the response of major enzymatic antioxidants (ascorbate peroxidase, catalase, catalase peroxidase, and superoxide dismutase) in both partners under thermal stress in a bleaching susceptible (Acropora millepora) and tolerant coral (Montipora digitata), and correlate these processes to the phenotypic bleaching response. Both corals are known to harbour different symbiont types (ITS2-types C3 vs. C15) and previous work has established the varying thermal susceptibility for a number of Indo-Pacific corals harbouring these types at the chosen study site (Fisher et al., 2012). Our hypothesis was, following the OTB, that (a) antioxidant defences in Symbiodinium will increase in response to elevated temperature and declining photosynthetic performance, followed by (b) an increase in antioxidant defences of the coral host with (c) the occurrence of bleaching in the susceptible coral at high temperatures as a result of (a) and (b). For the tolerant coral M. digitata (with Symbiodinium type C15), previous work has shown that photoprotective measures might be a key element of thermal tolerance (Fisher et al., 2012), so we hypothesised that no significant antioxidant response would occur in either the symbiont or host, consistent with the OTB that identifies the symbiont as the origin of excessive ROS production under thermal stress.

\section{Material and methods}

\subsection{Experimental setup and sample processing}

Fragments of the scleractinian corals Acropora millepora (cream morph) and Montipora digitata (green morph) were collected from five different colonies per species $(\mathrm{N}=5)$ on the Heron Island reef flat (2-4 m depth) in Feb 2012 (Heron Island Research Station, HIRS, $23^{\circ} 33^{\prime} \mathrm{S}, 151^{\circ} 54^{\prime} \mathrm{E}$ ) under the GBR Marine Park permit G12/34800.1. Each colony provided coral explants that were haphazardly allocated to two 60 L flow-through seawater tanks (1.3-1.5 $\mathrm{L} \mathrm{min}^{-1}$ ), maintained under shade cloth, exposing the corals to $~ 25 \%$ of the natural irradiance throughout the experiment (i.e., $~ 400-600 \mu \mathrm{mol}$ quanta $\mathrm{m}^{-2} \mathrm{~s}^{-1}$ on a clear sunny day at noon; LI-COR Quantum light meter LI-189 with cosine sensor, LI-COR Inc., Lincoln, NE, USA). Since all of the prepared explants were thumb-sized (minimising self-shading effects of large branching colonies) and all explants were maintained towards the centre of the tank throughout the experiment, we assume that all explants experienced a homogenous light field. Even though our experiment was conducted in only two tanks, a high tank-volume-to-coral-biomassratio with a high water flow minimised any effects of pseudoreplication, while ensuring identical treatment conditions to all explants (sensu Brown et al., 2002a).

Corals were acclimated to experimental light conditions for 9 days prior to temperature ramping. Ambient photosynthetically active radiation (PAR) conditions during the experimental period were recorded with an ODYSSEY PAR cosine recorder (DATAFLOW Systems Pty Ltd., Christchurch, New Zealand). Half of the explants were used for analysis of host cellular and apoptotic signalling (Hawkins et al., 2014), whereas the other half were used to assess the activity of enzymatic antioxidants (this study). After sampling on Day 0, temperature in one of the tanks was increased by $1{ }^{\circ} \mathrm{C}$ day ${ }^{-1}$ to a final average temperature of $33{ }^{\circ} \mathrm{C}$ $\left( \pm 0.8^{\circ} \mathrm{C}\right)$, while the minimal temperature of the control tank was set to $27.5^{\circ} \mathrm{C}$, based on long-term seawater temperature data for the Heron Island reef flat for February (AIMS, 2013). Both tanks expressed a diel temperature cycle that was influenced by tide cycles and solar heating (Fig. 2). Mean light intensities and mean temperature in the control tank were highly correlated during acclimation and the experimental phase (Pearson correlation, $\mathrm{r}=0.89, \mathrm{p}<0.0001, \mathrm{~N}=14$ ). Average control temperature over the experimental period was $28.5^{\circ} \mathrm{C}$ $\left( \pm 0.9^{\circ} \mathrm{C}\right)$. Sampling occurred immediately after noon on Days $0,5,7$, and 9 , and explants were flash frozen in liquid nitrogen and stored at $-80^{\circ} \mathrm{C}$ until analysis.

\subsection{Photobiological variables and sample processing}

Effective and maximum quantum yields of algal PSII $\left(\Delta \mathrm{F} / \mathrm{F}_{\mathrm{m}}^{\prime}, \mathrm{F}_{\mathrm{v}} / \mathrm{F}_{\mathrm{m}}\right.$, respectively), measured using pulse amplitude modulation fluorometry (MI: 9-11, SI: 8, saturation width: $0.8 \mathrm{~s}$, Gain up to 10 for bleached corals, Damp: 2-3; Diving-PAM, Heinz Walz GmbH, Effeltrich, Germany), were monitored on five replicate explants per species and treatment throughout the experiment. Data were recorded daily at noon and 30 min after sunset, with the fibre optic positioned at the same spot on the same explant at each time point. Maximum midday excitation pressure on photosystem II $\left(\mathrm{Q}_{\mathrm{m}}\right)$, hereafter referred to as light pressure, was calculated as $\mathrm{Q}_{\mathrm{m}}=1-\left[\left(\Delta \mathrm{F} / \mathrm{F}^{\prime}{ }_{\mathrm{m}}\right.\right.$ at noon $) /\left(\mathrm{F}_{\mathrm{v}} / \mathrm{F}_{\mathrm{m}}\right.$ at dusk on Day 0)] (as defined by Fisher et al., 2012).

All samples were processed in a $4{ }^{\circ} \mathrm{C}$ environment, and samples maintained on ice. The whole surface of coral explants was brushed with a water pik using $8 \mathrm{~mL}$ lysis buffer ( $50 \mathrm{mM}$ phosphate, $0.1 \mathrm{mM}$ EDTA, $10 \%$ [v/v] glycerol, pH 7.0), and three $500 \mu \mathrm{L}$ aliquots for chlorophyll $a(\mathrm{Chl} a)$ analysis, symbiont genotyping and cell density determination were taken. Following initial centrifugation $(2,000 \times g, 5 \mathrm{~min})$ to pellet the remaining Symbiodinium cells, the supernatant containing the coral tissue was centrifuged again $(16,000 \times \mathrm{g}$, $5 \mathrm{~min})$ to remove any particulate matter, aliquoted, flash frozen in liquid nitrogen and stored at $-80{ }^{\circ} \mathrm{C}$. The Symbiodinium pellets for antioxidant analysis were flash frozen and stored at $-80^{\circ} \mathrm{C}$. Lysis of Symbiodinium pellets after four wash cycles $(2,000 \times \mathrm{g}, 5 \mathrm{~min})$ was performed in lysis buffer using $200 \mathrm{mg}$ glass beads (710-1180 $\mu \mathrm{m}$; Sigma-Aldrich) in a bead mill $\left(50 \mathrm{~Hz}, 3 \mathrm{~min}, 4{ }^{\circ} \mathrm{C}\right.$, Qiagen tissue lyser, Qiagen N.V., Hilden, Germany). All cell lysates were centrifuged $(16,000 \times \mathrm{g}, 5 \mathrm{~min})$, and supernatants aliquoted and frozen at $-80^{\circ} \mathrm{C}$.

Symbiont cell densities were quantified via haemocytometer counts and normalised to coral explant surface area, which was determined via the wax-dipping method (Stimson and Kinzie, 1991). Symbiont ITS2

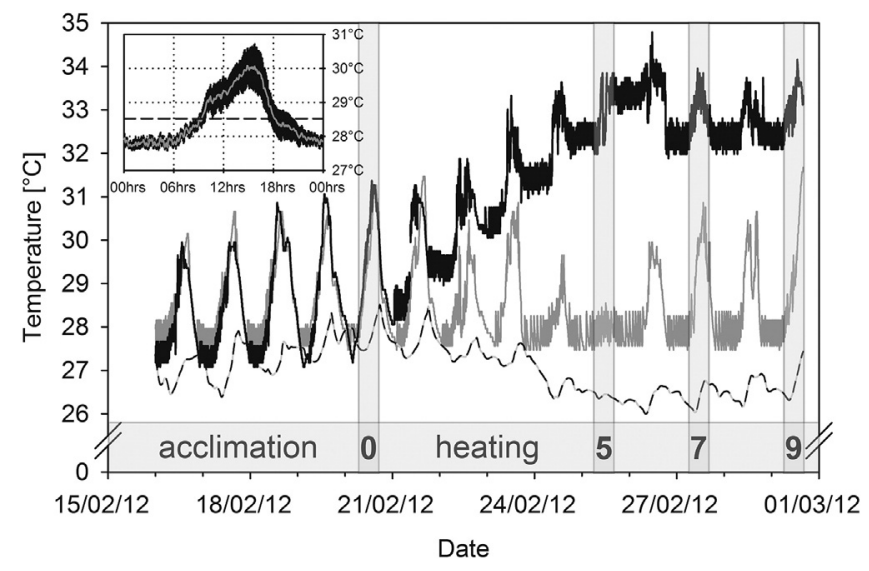

Fig. 2. Experimental temperature profile. Temperature profile of experimental treatments at $28{ }^{\circ} \mathrm{C}$ (grey) and $33^{\circ} \mathrm{C}$ (black) in a flow-through tank system during acclimation (prior Day 0 ) and the experimental period (sampling on Days 0, 5, 7, and 9; time-points highlighted by shading). Ambient water temperature at $2.04 \mathrm{~m}$ water depth [Heron Island relay pole 3 (AIMS, 2013)] depicted as black-grey dashed line. Average daily temperature variation in the control tank over the whole period is shown as graph insert (mean $\pm 95 \%$ $\mathrm{Cl}, \mathrm{N}=3,937$, with overall mean of $28.5^{\circ} \mathrm{C}$ shown as dashed line). 
identity was determined after previously published methods (Logan et al., 2010). Briefly, ITS2 rDNA regions were by PCR-amplified using the forward primer itsD ( $5^{\prime}$-GTG AAT TGC AGA ACT CCG TG-3') and reverse primer its2rev2 (5'-CCT CCG CCT ACT TAT ATG CTT-3'). PCR amplicons were visualised via gel electrophoresis to check for correct amplicon size and non-specific amplifications. Successful amplifications were purified using ExoSAP-IT (Global Science) and sequenced in both directions by Macrogen Inc. (Seoul, South Korea). ITS genotypes were identified by comparison against the Geosymbio database (Franklin et al., 2012). Chlorophyll was extracted over $48 \mathrm{~h}$ in $1-2 \mathrm{~mL} \mathrm{~N}, \mathrm{~N}-$ dimethylformamide at $4{ }^{\circ} \mathrm{C}$ in the dark. After centrifugation $(5 \mathrm{~min}$, $\left.3,900 \times g, 4^{\circ} \mathrm{C}\right), 3 \times 200 \mu \mathrm{L}$ of the supernatant were spectrophotometrically measured at $646.8 \mathrm{~nm}, 663.8 \mathrm{~nm}$, and $750 \mathrm{~nm}$ in 96-well plates (UVStar, Greiner Bio-One GmbH, Germany). Chl $a$ concentrations were determined after optical path length correction $(0.555 \mathrm{~cm})$, using the equations of Porra et al. (1989).

\subsection{Biochemical analysis}

Host and Symbiodinium samples were analysed for superoxide dismutase (SOD), catalase (CAT; host), catalase peroxidase (KatG; symbiont only), and ascorbate peroxidase (APX) activity, since these enzymes represent the main enzymatic pathways for superoxide and hydrogen peroxide detoxification.

\subsubsection{Superoxide dismutase}

SOD assays were performed using the riboflavin/nitroblue tetrazolium (RF/NBT) assay in a microtiter plate format (Beauchamp and Fridovich, 1971; Fryer et al., 1998). Lysate or SOD standard (20 $\mu \mathrm{L})$ was measured in a final reaction mixture of $300 \mu \mathrm{L}$ potassium phosphate buffer (50 mM, pH 7.8) containing EDTA (0.1 mM), riboflavin $(1.3 \mu \mathrm{M})$, L-methionine (10 mM), NBT (57 $\mu \mathrm{M})$, and Triton X-100 (0.025\% (v/v)). Absorbance was read at $560 \mathrm{~nm}$ both immediately and after $10 \mathrm{~min}$ incubation under a homogeneous light field (130 $\mu$ mol quanta $\mathrm{m}^{-2} \mathrm{~s}^{-1}$ ) at $25^{\circ} \mathrm{C}$ using a microtiter plate reader (Biochrom Anthos 2010 Microplate Reader, Biochrom Ltd., Cambridge, UK). Standards and samples were measured using the same reaction mixture and a sigmoidal 5parameter semi-logarithmic standard curve (24 standard levels) was used to determine SOD activity of samples. One unit of SOD activity inhibited the NBT reduction by $50 \%$.

\subsubsection{Ascorbate peroxidase}

APX activity was assessed by monitoring the oxidation of ascorbate at $290 \mathrm{~nm}$ over $3 \mathrm{~min}$ at $25^{\circ} \mathrm{C}$ (UV-Vis Spectrophotometer UV-2550, Shimadzu Corp., Japan), using $100 \mu \mathrm{L}$ lysate in a final reaction mixture of $700 \mu \mathrm{L}$ potassium phosphate buffer ( $50 \mathrm{mM}$, pH 7.0), EDTA $(0.1 \mathrm{mM})$, ascorbate $(0.3 \mathrm{mM})$ and hydrogen peroxide $(0.1 \mathrm{mM})$ (Nakano and Asada, 1981). Activity was determined with $\varepsilon=$ $2.8 \mathrm{mM}^{-1} \mathrm{~cm}^{-1}$.

\subsubsection{Catalase and catalase peroxidase}

CAT and KatG activity were determined spectrophotometrically using $100 \mu$ L lysate ( $1: 10$ diluted for host samples) in a total reaction volume of $700 \mu \mathrm{L}$, containing potassium phosphate buffer $(50 \mathrm{mM}$, $\mathrm{pH} 7.0)$, EDTA $(0.1 \mathrm{mM})$, and hydrogen peroxide $(14 \mathrm{mM})$. The reaction was monitored for $3 \mathrm{~min}$ at $240 \mathrm{~nm}$ and $25^{\circ} \mathrm{C}$ in quartz cuvettes and activities calculated using an extinction coefficient of $43.6 \mathrm{M}^{-1} \mathrm{~cm}^{-1}$ (Beers and Sizer, 1952).

Total soluble protein was determined using the improved Bradford method with BSA as protein standard (Zor and Selinger, 1996). After checking that protein per cell (for Symbiodinium) and protein per unit surface area (for host) were not affected by treatments, all enzyme activities were expressed as specific activities ( $\mathrm{U} \mathrm{mg}^{-1}$ protein). One enzyme unit is defined as the amount of enzyme that catalyses $1 \mu \mathrm{mol}$ of superoxide (SOD) or hydrogen peroxide (APX, CAT, KatG) per minute.

\subsection{Statistical analyses}

Baseline physiological variables at the beginning of the experiment (Day 0) were compared using ANOVA, after checking for normality (Shapiro-Wilk test) and equal variance (Levene test). $\mathrm{F}_{\mathrm{v}} / \mathrm{F}_{\mathrm{m}}$ and $\mathrm{Q}_{\mathrm{m}}$ results were arcsine square root and $\log _{10}\left(\mathrm{Q}_{\mathrm{m}}+0.2\right)$ transformed, respectively. In case of unequal variances, Welch ANOVA results are reported. Responses of bleaching proxies, photobiology and antioxidants over time were analysed with a repeated measures ANOVA (rmANOVA) with the fixed factors 'species' and 'temperature' and their interaction 'species $\times$ temperature'. In case the interaction term was not significant for between- or within-subject effects, it was removed to obtain a minimal adequate model. Results of Pillai's trace test, or where Mauchly's sphericity test was significant, epsilonadjusted univariate F-test (Greenhouse-Geisser; G-G) are reported. To prevent the loss of the whole replicate data series for the rmANOVA, enzyme activities for missing intermediate replicate points from two colonies (A. millepora: $28^{\circ} \mathrm{C}$, Day 5, symbiont data and Day 7, host and symbiont data) were estimated by extrapolating from measurements of the previous and following sampling points. The linear extrapolation located the estimated data points within the distribution of the remaining four replicates. Thus, we conclude that this extrapolation had no effect on the statistical outcome of the analysis. Analysis was conducted with SAS JMP 10.0.0 (SAS Institute Inc., Cary, NC, USA).

\section{Results}

\subsection{Symbiont identity, photobiological responses, and bleaching}

Symbionts in all colonies were identified as Symbiodinium ITS2 types C3 (A. millepora) and C15 (M. digitata), respectively. Both corals exhibited significant differences in their total $\mathrm{Chl} a$ content at the beginning of the experiment, which was primarily driven by a two-fold higher Chl $a$ content per symbiont cell in the Symbiodinium C15 population in $M$. digitata rather than by differing symbiont densities (Table 1 ).

High temperatures elicited significantly different photophysiological responses $\left(\mathrm{F}_{\mathrm{v}} / \mathrm{F}_{\mathrm{m}}\right.$ and $\left.\mathrm{Q}_{\mathrm{m}}\right)$ in the two coral species (Table 2, Fig. 3a-d). In A. millepora at $33^{\circ} \mathrm{C}$, maximum quantum yield dropped considerably after Day 5, reaching 49\% of the control value on Day 8. In the same period, $\mathrm{Q}_{\mathrm{m}}$ increased to $0.75-0.8$, whereas in $M$. digitata, declines in $\mathrm{F}_{\mathrm{v}} / \mathrm{F}_{\mathrm{m}}$ at $33{ }^{\circ} \mathrm{C}$ were minor ( $94 \%$ of the control value on Day 8) with $\mathrm{Q}_{\mathrm{m}}$ reaching a maximum value of 0.2 .

A. millepora, but not $M$. digitata, visibly bleached at $33^{\circ} \mathrm{C}$. Coral mortality (tissue sloughing and visible algal overgrowth of skeleton) in A. millepora was first detected on Day 7 (1 out of 5 replicates) and increased to $60 \%$ (3 of 5) on Day 9. Thus, comparative statistics between both corals was only possible until Day 7 . The negative effect of high temperature on holobiont $\mathrm{Chl}$ a content over time was species-specific to A. millepora, and declining values after Day 5 were a cumulative effect of the loss of symbiont cells and pigment content per symbiont (Table 2, Fig. 3e, Fig. S1). By Day 7, the four remaining A. millepora explants had lost $\sim 70 \%$ of their Chl $a$ content. In contrast, after 9 days at $33{ }^{\circ} \mathrm{C}$, holobiont Chl $a$ content of $M$. digitata was at control levels.

\subsection{Antioxidant features}

Differences in baseline antioxidant enzyme activities between both coral species were detected for symbiont SOD, APX, and KatG, with Symbiodinium C3 in A. millepora having consistently higher activities than Symbiodinium C15 in M. digitata at $28{ }^{\circ} \mathrm{C}$ (up to 10 -fold for APX). Host activities were only significantly different for CAT, where activity of $A$. millepora corresponded to $\sim 72 \%$ of the activity in $M$. digitata (Table 1). Comparison between compartments of the coral symbiosis indicated that baseline activity of hydrogen peroxide scavenging via $\mathrm{CAT} / \mathrm{KatG}$ was consistently higher in the host than the symbionts. Activities were higher by a factor of $\sim 5$ in A. millepora and $\sim 23$ in M. digitata. 
Table 1

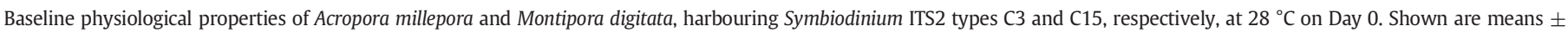

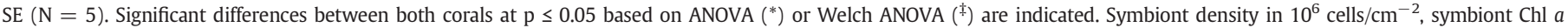
content in $\mathrm{pg} \mathrm{cell}^{-1}$, holobiont $\mathrm{Chl} a$ content in $\mu \mathrm{g} \mathrm{cm}{ }^{-2}$ and enzyme activities in $\mathrm{U} \mathrm{mg}^{-1}$ protein.

\begin{tabular}{|c|c|c|c|}
\hline & Acropora millepora (C3) & Montipora digitata (C15) & F-statistics \\
\hline $\mathrm{F}_{\mathrm{v}} / \mathrm{F}_{\mathrm{m}}$ & $0.670 \pm 0.005$ & $0.646 \pm 0.003$ & $\mathrm{~F}_{1,8}=13.930, \mathrm{p}=0.0058^{*}$ \\
\hline Symbiont density & $1.76 \pm 0.25$ & $1.99 \pm 0.28$ & $\mathrm{~F}_{1,8}=0.353, \mathrm{p}=0.5690$ \\
\hline Symbiont Chl $a$ content & $1.85 \pm 0.11$ & $4.05 \pm 0.12$ & $\mathrm{~F}_{1,8}=174.494, \mathrm{p}<0.0001^{*}$ \\
\hline Holobiont Chl $a$ content & $3.11 \pm 0.38$ & $7.84 \pm 0.68$ & $\mathrm{~F}_{1,8}=37.495, \mathrm{p}=0.0003^{*}$ \\
\hline Host SOD & $17.26 \pm 1.60$ & $15.63 \pm 1.60$ & $\mathrm{~F}_{1,8}=0.517, \mathrm{p}=0.4928$ \\
\hline Host CAT & $118.15 \pm 12.52$ & $164.02 \pm 10.60$ & $\mathrm{~F}_{1,8}=7.821, \mathrm{p}=0.0233^{*}$ \\
\hline Symbiont SOD & $78.23 \pm 6.01$ & $50.41 \pm 6.91$ & $\mathrm{~F}_{1,8}=9.228, \mathrm{p}=0.0161^{*}$ \\
\hline Symbiont APX & $1.41 \pm 0.04$ & $0.13 \pm 0.01$ & $\mathrm{~F}_{1,4.935}=862.112, \mathrm{p}<0.0001^{\ddagger}$ \\
\hline Symbiont KatG & $24.21 \pm 0.55$ & $7.32 \pm 1.26$ & $\mathrm{~F}_{1,5.448}=150.251, \mathrm{p}<0.0001^{\ddagger}$ \\
\hline
\end{tabular}

Baseline SOD activity on the other hand was 3-5 times higher in the symbiont than the host (Fig. 4).

Significant changes over the course of the experiment were observed for hydrogen peroxide scavenging by symbiont KatG and host CAT, independent of species (Table 2, Fig. 4, 5). An influence of temperature, however, was only detected for host CAT and this effect was also independent of species (Table 2). In A. millepora at $33^{\circ} \mathrm{C}$, host CAT activity reached $\sim 190 \mathrm{U} \mathrm{mg}-{ }^{1}$ on Day 5 and remained at this level until the end of the experiment (20-43\% above control, Fig. 5c). CAT activity in M. digitata at $33{ }^{\circ} \mathrm{C}$ was, on average, $23-46 \%$ above the control values between Days 5 and 9 (Fig. 5d). Due to the high degree of mortality in A. millepora at $33^{\circ} \mathrm{C}$, data for statistical analysis are limited to Days $0-7$. Nevertheless, it should be highlighted that the two surviving colonies of A. millepora on Day 9 were characterised by a very low Chl $a$ content (13\% of control values). The symbiont population in these two colonies expressed twice the KatG activity $(+105 \%)$ and very low APX activities $(-80 \%)$ relative to the control.

A number of significant correlations in enzyme activity in both symbiotic compartments were found (Table 3). Under ambient conditions, there was a significant positive correlation within the SOD-APX pathway in the symbionts of $A$. millepora, while symbiont KatG activity was negatively correlated with the activity of this pathway. SOD activities in the symbiont and host compartment were positively correlated in A. millepora at $28{ }^{\circ} \mathrm{C}$. The increase in host CAT activity at $33{ }^{\circ} \mathrm{C}$ in A. millepora was negatively correlated with SOD activity in host and symbiont. In M. digitata under ambient conditions, activities of APX and KatG in the symbiont were positively correlated with CAT in the host compartment, but this correlation was not significant at high temperatures. Only symbiont SOD and APX activity were positively correlated at $33^{\circ} \mathrm{C}$.

Although introducing additional uncontrolled variability into the experimental design, the varying mean light levels over the course of our experiment (Fig. 3c, d) allowed an assessment of the light dependence of the antioxidant enzyme activity under ambient conditions. Daily mean light level and antioxidant enzyme activity were correlated only in the symbionts of A. millepora, where SOD and APX activity were positively affected by increasing light intensities (Table 3 ).

\section{Discussion}

This study contrasted the temperature response of two common Indo-Pacific corals, known to possess different bleaching thresholds,

Table 2

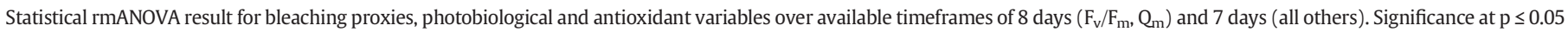

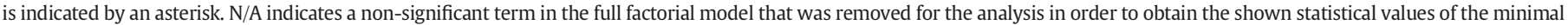
adequate model. Symbiont density in cells $\mathrm{cm}^{-2}$, symbiont Chl $a$ in pg cell ${ }^{-1}$, holobiont Chl $a$ content in $\mu g \mathrm{~cm}^{-2}$, and enzyme activities are in $\mathrm{U}$ mg ${ }^{-1}$ protein.

\begin{tabular}{|c|c|c|c|c|c|c|c|}
\hline \multirow[b]{2}{*}{ Variable } & \multicolumn{3}{|c|}{ Between-subject effects } & \multirow[b]{2}{*}{ Time } & \multicolumn{3}{|l|}{ Within-subject effects } \\
\hline & Species & Temperature & $\begin{array}{l}\text { Species } \times \\
\text { temperature }\end{array}$ & & Time $\times$ species & Time $\times$ temperature & $\begin{array}{l}\text { Time } \times \text { species } \times \\
\text { temperature }\end{array}$ \\
\hline $\mathrm{Fv} / \mathrm{Fm}$ & $\begin{array}{l}\mathrm{F}_{1,14}=20.568 \\
\mathrm{p}=0.0005^{*}\end{array}$ & $\begin{array}{l}\mathrm{F}_{1,14}=136.145 \\
\mathrm{p}<0.0001^{*}\end{array}$ & $\begin{array}{l}\mathrm{F}_{1,14}=94.792 \\
\mathrm{p}<0.0001^{*}\end{array}$ & $\begin{array}{l}\mathrm{F}_{1.736,24.308}=8.368 \\
\mathrm{p}=0.0025^{*}\end{array}$ & $\begin{array}{l}F_{1.736,24.308}=1.736 \\
p=0.1683\end{array}$ & $\begin{array}{l}\mathrm{F}_{1.736,24.308}=185.076 \\
\mathrm{p}<0.0001^{*}\end{array}$ & $\begin{array}{l}\mathrm{F}_{1.736,24.308}=129.710 \\
\mathrm{p}<0.0001^{*}\end{array}$ \\
\hline$Q_{m}$ & $\begin{array}{l}\mathrm{F}_{1,14}=6.128 \\
\mathrm{p}=0.0267^{*}\end{array}$ & $\begin{array}{l}\mathrm{F}_{1,14}=41.002 \\
\mathrm{p}<0.0001^{*}\end{array}$ & $\begin{array}{l}\mathrm{F}_{1,14}=20.890 \\
\mathrm{p}=0.0004^{*}\end{array}$ & $\begin{array}{l}\mathrm{F}_{7,8}=28.770 \\
\mathrm{p}<0.0001^{*}\end{array}$ & $\begin{array}{l}\mathrm{F}_{7,8}=0.900 \\
\mathrm{p}=0.5485\end{array}$ & $\begin{array}{l}\mathrm{F}_{7,8}=15.198 \\
\mathrm{p}=0.0005^{*}\end{array}$ & $\begin{array}{l}\mathrm{F}_{7,8}=9.415 \\
\mathrm{p}=0.0026^{*}\end{array}$ \\
\hline $\begin{array}{l}\text { Symbiont } \\
\text { density }\end{array}$ & $\begin{array}{l}\mathrm{F}_{1,15}=4.597 \\
\mathrm{p}=0.0488^{*}\end{array}$ & $\begin{array}{l}F_{1,15}=0.662 \\
p=0.4287\end{array}$ & $\begin{array}{l}\mathrm{F}_{1,15}=0.055 \\
\mathrm{p}=0.8185\end{array}$ & $\begin{array}{l}\mathrm{F}_{2,14}=1.483 \\
\mathrm{p}=0.2605\end{array}$ & $\begin{array}{l}\mathrm{F}_{2,14}==1.996 \\
\mathrm{p}=0.1727\end{array}$ & $\begin{array}{l}\mathrm{F}_{2,14}=0.806 \\
\mathrm{p}=0.4663\end{array}$ & $\begin{array}{l}\mathrm{F}_{2,14}=4.4054 \\
\mathrm{p}=0.0328^{*}\end{array}$ \\
\hline $\begin{array}{l}\text { Symbiont } \\
\text { Chl } a \text { content }\end{array}$ & $\begin{array}{l}\mathrm{F}_{1,15}=72.899 \\
\mathrm{p}<0.0001^{*}\end{array}$ & $\begin{array}{l}F_{1,15}=0.107 \\
p=0.7486\end{array}$ & $\begin{array}{l}\mathrm{F}_{1,15}=6.689 \\
\mathrm{p}=0.0207^{*}\end{array}$ & $\begin{array}{l}\mathrm{F}_{2,14}=4.736 \\
\mathrm{p}=0.0269^{*}\end{array}$ & $\begin{array}{l}\mathrm{F}_{2,14}=2.752 \\
\mathrm{p}=0.0982\end{array}$ & $\begin{array}{l}\mathrm{F}_{2,14}=7.142 \\
\mathrm{p}=0.0073^{*}\end{array}$ & $\begin{array}{l}\mathrm{F}_{2,14}=3.078 \\
\mathrm{p}=0.0780\end{array}$ \\
\hline $\begin{array}{l}\text { Holobiont Chl } \\
a \text { content }\end{array}$ & $\begin{array}{l}\mathrm{F}_{1,15}=39.842 \\
\mathrm{p}<0.0001^{*}\end{array}$ & $\begin{array}{l}F_{1,15}=2.650 \\
p=0.1244\end{array}$ & $\begin{array}{l}\mathrm{F}_{1,15}=5.441 \\
\mathrm{p}=0.0340^{*}\end{array}$ & $\begin{array}{l}\mathrm{F}_{1.439,21.589}=0.1158 \\
\mathrm{p}=0.8250\end{array}$ & $\begin{array}{l}\mathrm{F}_{1.439,21.589}=0.732 \\
\mathrm{p}=0.4496\end{array}$ & $\begin{array}{l}\mathrm{F}_{1.439,21.589}=8.132 \\
\mathrm{p}=0.0048^{*}\end{array}$ & $\begin{array}{l}\mathrm{F}_{1.439,21.589}=5.137 \\
\mathrm{p}=0.0231^{*}\end{array}$ \\
\hline Host SOD & $\begin{array}{l}\mathrm{F}_{1,16}=0.001 \\
\mathrm{p}=0.9818\end{array}$ & $\begin{array}{l}\mathrm{F}_{1,16}=0.521 \\
\mathrm{p}=0.4810\end{array}$ & $\mathrm{~N} / \mathrm{A}$ & $\begin{array}{l}\mathrm{F}_{2,15}=0.654 \\
\mathrm{p}=0.5340\end{array}$ & $\begin{array}{l}\mathrm{F}_{2,15}=0.795 \\
\mathrm{p}=0.4698\end{array}$ & $\begin{array}{l}\mathrm{F}_{2,15}=0.707 \\
\mathrm{p}=0.5090\end{array}$ & $\mathrm{~N} / \mathrm{A}$ \\
\hline Host CAT & $\begin{array}{l}\mathrm{F}_{1,16}=44.655 \\
\mathrm{p}<0.0001^{*}\end{array}$ & $\begin{array}{l}\mathrm{F}_{1,16}=10.852 \\
\mathrm{p}=0.0046^{*}\end{array}$ & $\mathrm{~N} / \mathrm{A}$ & $\begin{array}{l}\mathrm{F}_{2,15}=9.277 \\
\mathrm{p}=0.0024^{*}\end{array}$ & $\begin{array}{l}\mathrm{F}_{2,15}=2.732 \\
\mathrm{p}=0.0973\end{array}$ & $\begin{array}{l}\mathrm{F}_{2,15}=4.312 \\
\mathrm{p}=0.0332^{*}\end{array}$ & $\mathrm{~N} / \mathrm{A}$ \\
\hline Symbiont SOD & $\begin{array}{l}\mathrm{F}_{1,16}=1.752 \\
\mathrm{p}=0.2042\end{array}$ & $\begin{array}{l}\mathrm{F}_{1,16}=7.260 \\
\mathrm{p}=0.0160^{*}\end{array}$ & $\mathrm{~N} / \mathrm{A}$ & $\begin{array}{l}\mathrm{F}_{1.403,22.452}=0.150 \\
\mathrm{p}=0.7855\end{array}$ & $\begin{array}{l}\mathrm{F}_{1.403,22.452}=5.549 \\
\mathrm{p}=0.0186^{*}\end{array}$ & $\begin{array}{l}F_{1.403,22.452}=0.470 \\
p=0.5638\end{array}$ & $\mathrm{~N} / \mathrm{A}$ \\
\hline Symbiont APX & $\begin{array}{l}\mathrm{F}_{1,15}=375.748 \\
\mathrm{p}<0.0001^{*}\end{array}$ & $\begin{array}{l}F_{1,15}=0.010 \\
p=0.9210\end{array}$ & $\begin{array}{l}\mathrm{F}_{1,15}=6.276 \\
\mathrm{p}=0.0243^{*}\end{array}$ & $\begin{array}{l}\mathrm{F}_{1.433,21.488}=0.063 \\
\mathrm{p}=0.8849\end{array}$ & $\begin{array}{l}\mathrm{F}_{1.433,21.488}=10.229 \\
\mathrm{p}=0.0019^{*}\end{array}$ & $\begin{array}{l}\mathrm{F}_{1.433,21.488}=0.529 \\
\mathrm{p}=0.5381\end{array}$ & $\begin{array}{l}\mathrm{F}_{1.433,21.488}=0.027 \\
\mathrm{p}=0.9361\end{array}$ \\
\hline $\begin{array}{l}\text { Symbiont } \\
\text { KatG }\end{array}$ & $\begin{array}{l}\mathrm{F}_{1,16}=120.166 \\
\mathrm{p}<0.0001^{*}\end{array}$ & $\begin{array}{l}F_{1,16}=1.972 \\
p=0.1794\end{array}$ & $\mathrm{~N} / \mathrm{A}$ & $\begin{array}{l}\mathrm{F}_{2,15}=7.623 \\
\mathrm{p}=0.0052^{*}\end{array}$ & $\begin{array}{l}\mathrm{F}_{2,15}=0.471 \\
\mathrm{p}=0.6335\end{array}$ & $\begin{array}{l}\mathrm{F}_{2,15}=2.5687 \\
\mathrm{p}=0.1098\end{array}$ & $\mathrm{~N} / \mathrm{A}$ \\
\hline
\end{tabular}

* $p \leq 0.05$ 

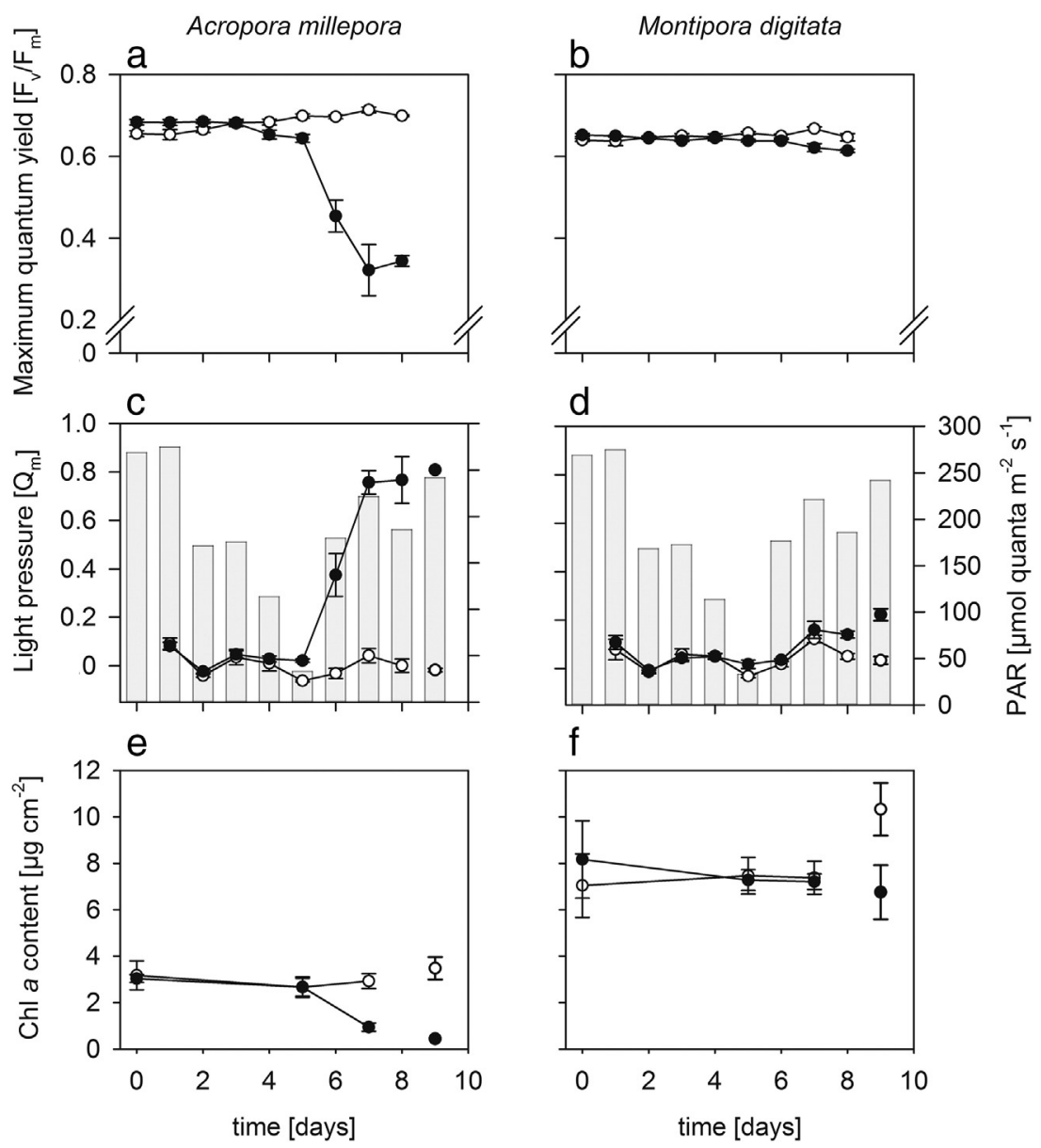

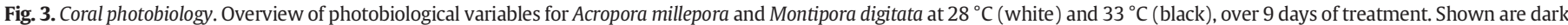

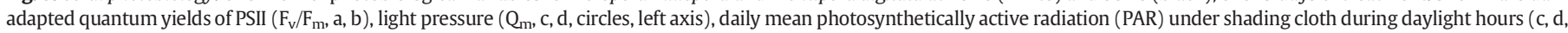

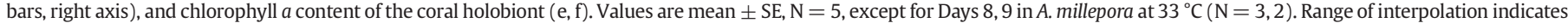
timeframe used for the statistical analysis (Table 2).

with a particular focus on the regulation of antioxidant enzymes in the symbiont and host compartments. When exposed to elevated temperatures, bleaching and photophysiological stress was evident in the thermally susceptible coral Acropora millepora. However, no significant upregulation of enzymatic antioxidant defences in its symbionts was observed at least until after the onset of bleaching (and host mortality in some replicates). Independent of bleaching susceptibility, increased scavenging of hydrogen peroxide $\left(\mathrm{H}_{2} \mathrm{O}_{2}\right)$ in the host compartment at high temperatures was observed in both coral species, and this preceded apparent algal PSII dysfunction and overall bleaching in A. millepora.

\subsection{Oxidative stress as a light and temperature response in host and symbiont}

A visual bleaching response in A. millepora was not apparent until at least after 7 days of exposure to heating. Substantial changes in the photobiological parameters $\mathrm{F}_{\mathrm{v}} / \mathrm{F}_{\mathrm{m}}$ and $\mathrm{Q}_{\mathrm{m}}$ coincided with this bleaching response, an observation that is consistent with previous findings (Hoegh-Guldberg and Jones, 1999; Warner et al., 1999; Ferrier-Pagès et al., 2007). High values of $Q_{m}$ show that, under full daylight, some of the PSII reaction centres were inactivated, indicating dynamic or chronic photoinhibition (Maxwell and Johnson, 2000). However, for advanced bleaching states (Day 9), increases in $Q_{m}$ might also be related to a brighter light environment for the remaining symbionts, as a result of a decrease in light absorption and increase in light scattering by the coral skeleton (Enríquez et al., 2005). In contrast to A. millepora, Montipora digitata was thermally robust and moderate reductions in
$\mathrm{F}_{\mathrm{v}} / \mathrm{F}_{\mathrm{m}}$ and increases in $\mathrm{Q}_{\mathrm{m}}$ suggest that the coral was within an acceptable range for its protective or photoacclimatory mechanisms, e.g., thermal dissipation of light energy (Gorbunov et al., 2001; Fisher et al., 2012).

While not actively manipulated in the experiment, changing ambient irradiance was positively correlated with the activity of the SODAPX pathway in the symbionts of A. millepora, but not in $M$. digitata, at $28{ }^{\circ} \mathrm{C}$. This pathway is commonly associated with photosynthesis as part of the water-water-cycle (Asada, 1999) and the distinct correlative response is most likely a result of different photosynthetic rates in the two coral species and the generation of superoxide as a side-product (e.g. Mehler reaction) in A. millepora. A stronger influence of light in A. millepora as result of a brighter symbiont microenvironment in response to less overall pigmentation (e.g., significantly lower holobiont Chl a content) would be consistent with the observations of higher symbiont baseline activities in Symbiodinium C3 and the marked drop in symbiont SOD and APX activity between Days 0 and 5 that coincided with decreasing light levels. The correlation between host and symbiont SOD at $28^{\circ} \mathrm{C}$ in $A$. millepora further supports the idea of a stronger influence of light in this coral, since varying tissue oxygen tensions due to daily fluctuations in light and photosynthesis would affect SOD in both compartments. Similarly, a positive correlation between tissue chlorophyll content and host SOD activity has been demonstrated for a range of symbiotic marine invertebrates (Shick and Dykens, 1985).

The photophysiological responses of $A$. millepora symbionts and the observed bleaching of the coral holobiont clearly demonstrate the adverse effect of high temperature on the stability of the symbiosis. 

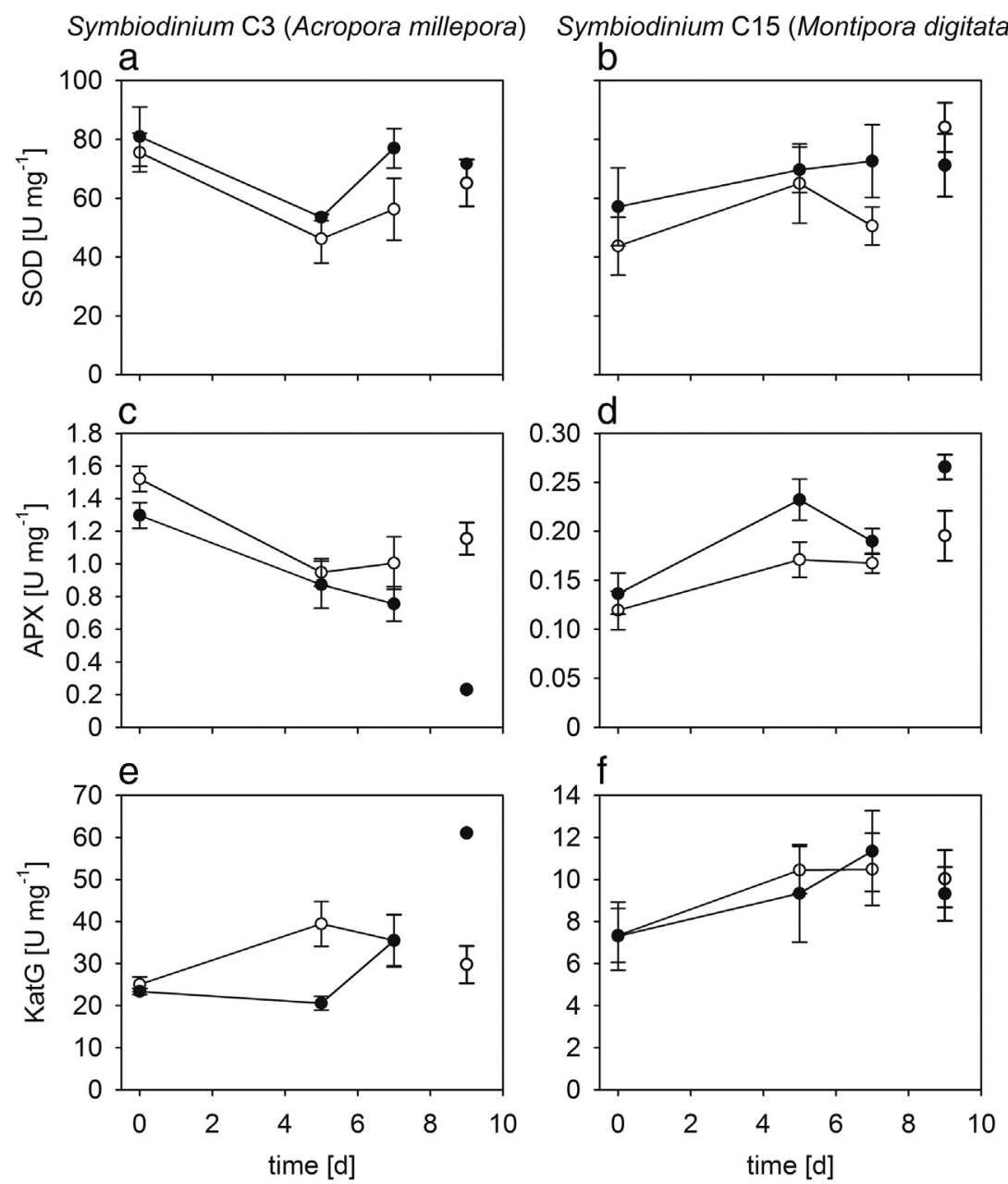

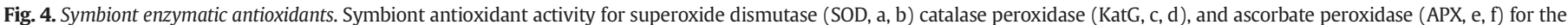

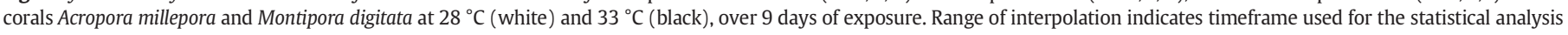

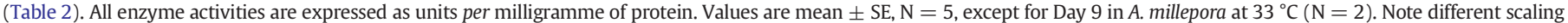
of axis in $c$, $d$ and e, f.

Surprisingly, however, the photophysiological impact of temperature was not reflected in the enzymatic antioxidant responses that we expected to accompany photo-oxidative stress in the symbiont as assumed by the Oxidative Theory of Coral Bleaching and demonstrated for thermally-challenged Symbiodinium in culture (Lesser, 1996; Krueger et al., 2014). Furthermore, we observed that increased CAT activity in both coral hosts was largely independent of the enzymatic removal of ROS in the symbiont or changes in host SOD. Thus, elevated CAT activity in both corals might result from increased metabolic activity in the host at higher temperatures (e.g., increased peroxisomal activity as a result of the mobilisation of reserves) and was in this case not indicative of bleaching susceptibility. The Oxidative Theory of Coral Bleaching suggests that hydrogen peroxide derived from photo-oxidative stress in the symbiont might leak into the host tissue, when symbiont defences are overwhelmed in bleaching corals (Downs et al., 2002). However, our observations show that when temperature is the dominant stressor, coral bleaching with compromised photosynthesis and loss of symbiont cells does not necessarily involve a connection of ROS fluxes between host and symbiont, since increases in host CAT activity at high temperatures can be independent of processes in the symbiont, and can occur in a temperature-tolerant and -sensitive coral. Furthermore, no photosynthetic dysfunction or significant changes in the symbiont SOD-APX pathway that would indicate enzymatic removal of ROS was observed within the first five days of thermal stress in A. millepora, whereas host CAT activity at $33^{\circ} \mathrm{C}$ was already elevated by Day 5 . The study of Hawkins et al. (2014), which was run in tandem with the current study, adds to this observation by illustrating a transient upregulation of host caspase-like enzyme activity - indicative of apoptoticlike cell death - in A. millepora at $33{ }^{\circ} \mathrm{C}$, that coincided with higher catalase-mediated hydrogen peroxide turnover in the host (this study) prior to photosynthetic breakdown in the symbionts. A causal relationship between the induction of nitric oxide synthesis and apoptosis under thermal stress in the host has been suggested (Hawkins et al., 2013; Hawkins et al., 2014), and the patterns seen in A. millepora highlight the role that ROS generally might play in the activation of apoptotic-like pathways in susceptible corals (Tchernov et al., 2011). Nevertheless, the point at which ROS production triggers apoptosis in the coral host appears to be species-specific, as a similar response with respect to host CAT in the bleaching-resistant $M$. digitata (this study) did not coincide with an upregulation of caspases or NO production (Hawkins et al., 2014).

While our study does not provide any further insights into the wellknown synergistic effects of light and temperature on bleaching physiology (Lesser et al., 1990; Lesser and Farrell, 2004; Downs et al., 2013), because we did not actively manipulate irradiance, it is notable that Day 5 in our experiment had the lowest mean irradiance, highlighting that elevated temperature was the primary stressor to induce the bleaching cascade in this experiment. From an ecological perspective, mass bleaching events, affecting multiple species across latitudinal and depth gradients, are primarily driven by anomalies in temperature rather than light (McWilliams et al., 2005; Sammarco et al., 2006; Eakin et al., 2009). With regard to the role of light and temperature in inducing 

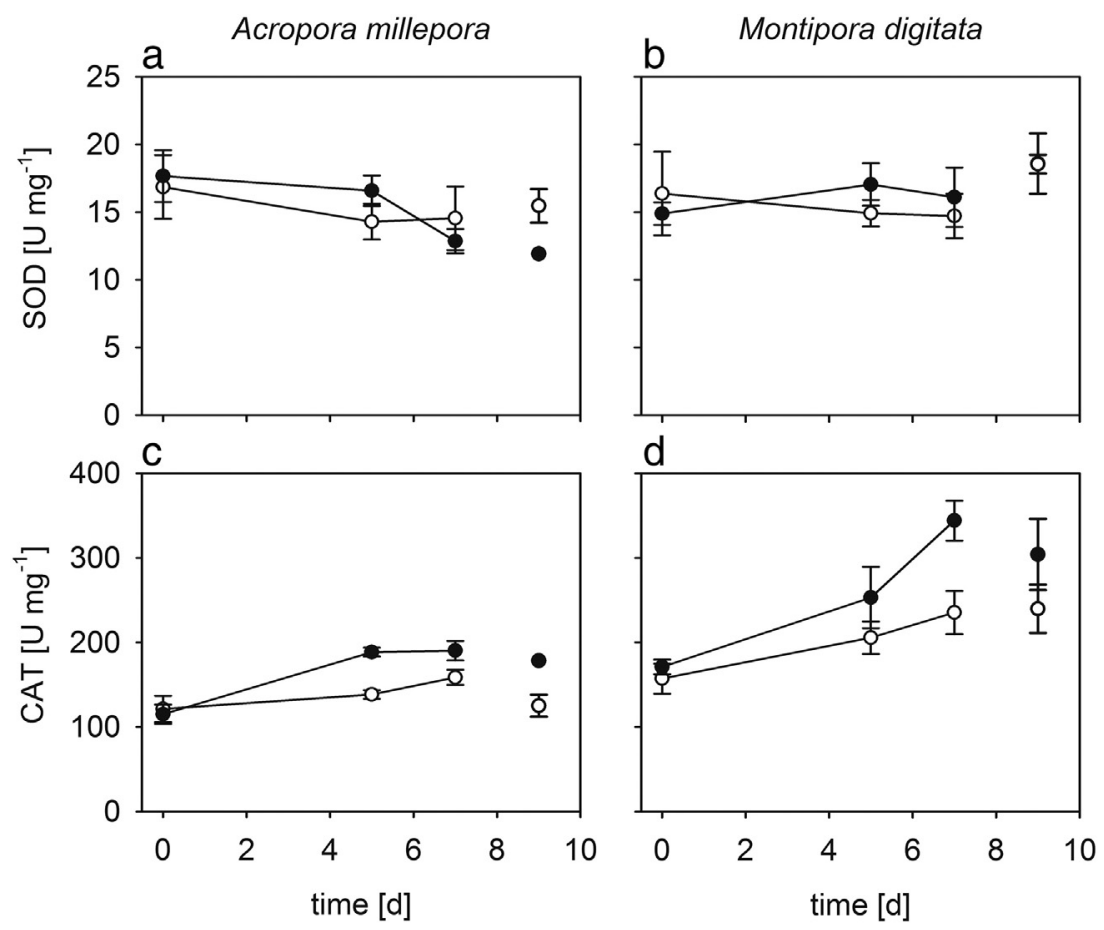

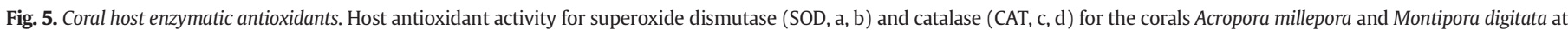

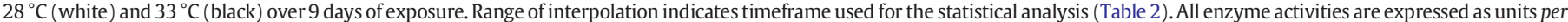
milligramme of protein. Values are mean $\pm \mathrm{SE}, \mathrm{N}=5$, except for Day 9 in $A$. millepora at $33^{\circ} \mathrm{C}(\mathrm{N}=2)$.

oxidative stress in both compartments of the cnidarian-dinoflagellate symbiosis, previous findings are ambiguous. While temperature stress increased symbiont SOD activity in Anemonia viridis (Richier et al., 2005) and Galaxea fascicularis (Higuchi et al., 2008; Higuchi et al., 2012), consistent with photophysiological stress and the formation of superoxide via the Mehler reaction (Asada, 1984), host SOD may (Montastraea faveolata; Downs et al., 2000; Stylophora pistillata; Yakovleva et al., 2004) or may not (Platygyra ryukyuensis; Yakovleva et al., 2004; Anemonia viridis; Richier et al., 2005) respond to elevated temperature. Similarly, increased host tissue levels of ROS, in the form of superoxide or hydroxyl radicals in response to elevated temperature can be either present (Aiptasia pulchella; Nii and Muscatine, 1997) or absent (Galaxea fascicularis; Higuchi et al., 2010). Clearly, cnidarian species differ significantly in their cellular physiology and the strategies employed to mitigate thermally-induced oxidative stress. In contrast, a large body of literature exists that clearly supports the existence and impact of oxidative stress in symbiont and host based on light and UV stress (Dykens and Shick, 1984; Lesser and Shick, 1989a; Lesser and Shick, 1989b; Dykens et al., 1992; Shick et al., 1995; Downs et al., 2002; Lesser and Farrell, 2004; Levy et al., 2006; Kuguru et al., 2010). It is these observations that have mainly shaped the Oxidative Theory of Coral Bleaching, identifying photo-oxidative stress in the symbiont and the leakage of ROS to the host compartment as the initiator of the bleaching cascade. It should also be noted that increased antioxidant activity (suggestive of higher ROS generation) in corals has been observed in response to pollution, aerial exposure and seasonal environmental variability, without eliciting a bleaching response (Liñán-Cabello et al., 2010; Teixeira et al., 2013).

\subsection{The role of heating regime and hydrogen peroxide production}

The impact of environmental stress depends on specific parameters such as amplitude, rate or frequency (Fig. 1). One of the important differences of our study to most of the previously mentioned studies is

Table 3

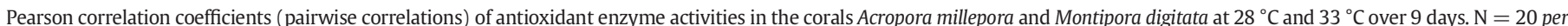

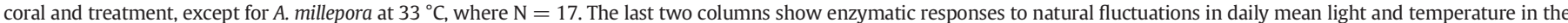
control treatment. Only significant correlations $(\mathrm{p} \leq 0.05)$ are shown.

\begin{tabular}{|c|c|c|c|c|c|c|c|c|c|c|}
\hline & \multicolumn{2}{|c|}{ Host SOD } & \multicolumn{2}{|c|}{ Host CAT } & \multicolumn{2}{|c|}{ Symbiont SOD } & \multicolumn{2}{|c|}{ Symbiont APX } & \multirow[t]{2}{*}{ Light } & \multirow[t]{2}{*}{ Temperature } \\
\hline & $28^{\circ} \mathrm{C}$ & $33^{\circ} \mathrm{C}$ & $28^{\circ} \mathrm{C}$ & $33^{\circ} \mathrm{C}$ & $28^{\circ} \mathrm{C}$ & $33^{\circ} \mathrm{C}$ & $28^{\circ} \mathrm{C}$ & $33^{\circ} \mathrm{C}$ & & \\
\hline \multicolumn{11}{|c|}{ Acropora millepora } \\
\hline Host SOD & - & - & & & & & & & n.s. & n.s. \\
\hline Host CAT & n.s. & -0.50 & - & - & & & & & n.s. & n.s. \\
\hline Symbiont SOD & 0.51 & n.s. & n.s. & -0.61 & - & - & & & 0.48 & 0.48 \\
\hline Symbiont APX & n.s. & n.s. & n.s. & n.s. & 0.71 & n.s. & - & - & 0.49 & 0.49 \\
\hline Symbiont KatG & -0.45 & -0.53 & n.s. & n.s. & -0.74 & n.s. & -0.69 & -0.54 & n.s. & n.s. \\
\hline \multicolumn{11}{|c|}{ Montipora digitata } \\
\hline Host SOD & - & - & & & & & & & n.s. & n.s. \\
\hline Host CAT & n.s. & n.s. & - & - & & & & & n.s. & n.s. \\
\hline Symbiont SOD & n.s. & n.s. & n.s. & n.s. & - & - & & & n.s. & n.s. \\
\hline Symbiont APX & n.s. & n.s. & 0.61 & n.s. & n.s. & 0.46 & - & - & n.s. & n.s. \\
\hline Symbiont KatG & n.s. & n.s. & 0.50 & n.s. & n.s. & n.s. & n.s. & n.s. & n.s. & n.s. \\
\hline
\end{tabular}


the applied heating rate in the experimental setup. Low heating rates profoundly delay the physiological response of the coral holobiont (Middlebrook et al., 2010) and the ramping rate of $1{ }^{\circ} \mathrm{C}_{\text {day }}{ }^{-1}$ used in the current study is considerably slower than in previous studies of antioxidant responses under thermal stress; these applied heating rates ranging from near-instantaneous to $4{ }^{\circ} \mathrm{C}$ hour $^{-1}$ (Yakovleva et al., 2004; Richier et al., 2005; Higuchi et al., 2008; Yakovleva et al., 2009; Higuchi et al., 2012; Downs et al., 2013; T. Higuchi and I. Yakovleva, personal communication). Coral reef-flat communities can experience temperature changes of $1{ }^{\circ} \mathrm{C}$ hour ${ }^{-1}$ during spring tides (Berkelmans and Willis, 1999), however temperature changes relevant to mass bleaching are usually slower, and therefore heating rates of $1{ }^{\circ} \mathrm{C}$ day ${ }^{-1}$ were applied in this study. Rapid temperature increases are not typically representative of bleaching conditions in the field. Moreover, they limit the capacity to measure and distinguish short- and long-term responses. For example, applying a $4{ }^{\circ} \mathrm{C}$ hour ${ }^{-1}$ temperature increase from $25{ }^{\circ} \mathrm{C}$ to $33{ }^{\circ} \mathrm{C}$ to the corals Acropora intermedia and Montipora digitata from the South China Sea resulted in a $90 \%$ symbiont loss within $48 \mathrm{~h}$ (Imbs and Yakovleva, 2012). It is unknown whether or how heating rate affects the specific mechanism by which bleaching occurs, i.e., the spectrum of responses from symbiont in situ degradation to host cell apoptosis and necrosis (reviewed in Weis, 2008), but it seems plausible that slow- $v s$. rapid heating should induce different cellular pathologies. Although not always feasible, the most realistic and ecologically relevant stress scenario should mimic the time scale and temperature profile of a natural bleaching event.

Photosynthetically-derived $\mathrm{H}_{2} \mathrm{O}_{2}$ has been suggested as the most likely ROS to move between both partners due to the fact that it has a longer lifetime than other ROS, a large diffusion radius, and no net charge (Winterbourn, 2008), potentially enabling it to move through the three chloroplastic membranes, the symbiont cell membrane and the symbiosome membrane complex (Wakefield et al., 2000) to enter the host cytosol (Lesser et al., 1990; Downs et al., 2002). Potential leakage of hydrogen peroxide from Symbiodinium and other dinoflagellates (but also extracellular generation of ROS) has indeed been shown experimentally (Palenik and Morel, 1990; Sandeman, 2006; Suggett et al., 2008; Saragosti et al., 2010). Our findings agree with previous studies that, depending on the coral species, catalase activity per unit protein is usually three to ten times higher (up to twenty-three times in $M$. digitata) in the host than in the symbiont (Yakovleva et al., 2004; Levy et al., 2006; Higuchi et al., 2008). Although never fully acknowledged before, this observation implies that the host has sufficient scavenging capacity to deal with symbiont-derived hydrogen peroxide. Using symbiont densities and biomass values of the two coral species investigated here, in combination with values of maximum released ROS per symbiont cell (as $\mathrm{H}_{2} \mathrm{O}_{2}$ equivalents) due to an oxidative burst (Mydlarz and Jacobs, 2004) or combined high light and temperature stress (Suggett et al., 2008; Roberty et al., 2015), the maximum release rates of hydrogen peroxide as simultaneous release from the whole symbiont population would only amount to $0.07-0.39 \%$ of the host's scavenging capacity via CAT (assuming saturating hydrogen peroxide levels for host CAT; Table 4). This number does not even include the activity of the host's other enzymatic and non-enzymatic $\mathrm{H}_{2} \mathrm{O}_{2}$ scavenging systems. Clearly, measurements of the amount and direction of ROS fluxes between both partners under stress are needed to confirm the notion that leaking $\mathrm{H}_{2} \mathrm{O}_{2}$ from the symbiont can indeed significantly challenge or harm the host (Lesser, 1997; Downs et al., 2002).

It is clear that we still have much to learn about the fluxes of ROS between host and symbiont. Admittedly, the absence of an antioxidant upregulation in the symbiont during the onset of thermal bleaching in our experiment does not preclude the potential occurrence of oxidative damage or increases in steady-state ROS levels per se, because neither was monitored. Furthermore, the role of other important photoprotective mechanisms that might have prevented ROS formation upstream of antioxidant enzymes, such as xanthophyll cycling (Brown
Table 4

Estimated maximum release of symbiont reactive oxygen species (ROS; as hydrogen peroxide equivalents) based on an oxidative burst (Mydlarz and Jacobs, 2004) ${ }^{1}$ and high light and high temperature $\left(\geq 1000 \mu \mathrm{mol}\right.$ photons $\left.\mathrm{m}^{-2} \mathrm{~s}^{-1} ; 32-33^{\circ} \mathrm{C}\right)$ in Symbiodinium B1 (Suggett et al., 2008) ${ }^{2}$ and A1 (Roberty et al., 2015) ${ }^{3}$ contrasted with host hydrogen peroxide scavenging capacity via catalase (CAT) for Acropora millepora and Montipora digitata at $28{ }^{\circ} \mathrm{C}$ (this study). Calculations are based on measured values for cell densities, protein content, and CAT activity at $28{ }^{\circ} \mathrm{C}$ on Day 0. Values from McGinty et al.(2012) were not considered, since the applied probe concentration for dichlorofluorescein diacetate ( $0.67 \mathrm{mM}$; DCFDA) was considerably higher than the recommended concentration ( $10 \mu \mathrm{M}$; Halliwell and Gutteridge, 2007), and therefore may have been cytotoxic. Note that host CAT activities represent the maximum activity as measured under saturating substrate concentrations.

\begin{tabular}{|c|c|c|}
\hline & $\begin{array}{l}\text { Acropora } \\
\text { millepora }\end{array}$ & $\begin{array}{l}\text { Montipora } \\
\text { digitata }\end{array}$ \\
\hline $\begin{array}{l}\mathrm{H}_{2} \mathrm{O}_{2} \text { release per symbiont cell } \\
{\left[\mathrm{pmol} \mathrm{min}^{-1} \text { cell }^{-1}\right]}\end{array}$ & \multicolumn{2}{|c|}{$\sim 0.042-0.11^{1} / 0.061^{2} / 0.21^{3}$} \\
\hline $\begin{array}{l}\text { Symbiont density } \\
\left.\text { [cells } \mathrm{cm}^{-2}\right]\end{array}$ & $\sim 1,800,000$ & $\sim 2,000,000$ \\
\hline $\begin{array}{l}\text { Symbiont } \mathrm{H}_{2} \mathrm{O}_{2} \text { release per unit surface area } \\
{\left[\mu \mathrm{mol} \mathrm{min} \mathrm{min}^{-1} \mathrm{~cm}^{-2}\right]}\end{array}$ & $\sim 0.076-0.378$ & $\sim 0.084-0.420$ \\
\hline $\begin{array}{l}\text { Host protein per unit surface area } \\
{\left[\mathrm{mg} \mathrm{cm}^{-2}\right]}\end{array}$ & $\sim 0.8$ & $\sim 0.8$ \\
\hline $\begin{array}{l}\text { Host CAT activity per unit host protein } \\
\qquad\left[\mathrm{U} \mathrm{mg} \mathrm{mg}^{-1}=\mu \mathrm{mol} \mathrm{min}{ }^{-1} \mathrm{mg}^{-1}\right]\end{array}$ & $\sim 120$ & $\sim 160$ \\
\hline $\begin{array}{l}\text { Host CAT activity per unit surface area } \\
{\left[\mu \mathrm{mol} \mathrm{min}-1 \mathrm{~cm}^{-2}\right]}\end{array}$ & $\sim 96$ & $\sim 128$ \\
\hline Maximum symbiont $\mathrm{H}_{2} \mathrm{O}_{2}$ release/host CAT activity & $\sim 0.08-0.39 \%$ & $\sim 0.07-0.33 \%$ \\
\hline
\end{tabular}

et al., 1999; Brown et al., 2002b; but also see Venn et al., 2006), must be considered. Future studies should combine measurements of ROS levels, oxidative damage, and the activities of enzymatic and nonenzymatic antioxidants. Monitoring the degree of oxidative damage to the symbiosome membrane complex as the interface between host and symbiont would also be valuable, as it could provide information on the extent of ROS flow between both partners, regardless of the origin.

\subsection{A third role for ROS and NO in coral bleaching?}

The observed trends of antioxidant and apoptosis-regulating enzymes and NO accumulation (Hawkins et al., 2014) in the coral holobiont point towards the importance of early physiological events in the host that may precede the photosynthetic dysfunction of the symbionts. Although highly speculative at this point, hydrogen peroxide might have an active role in the host's antipathogenic response towards its symbionts under bleaching conditions, particularly when the host has sufficient catalase activity to attenuate any self-harm. Symbiodinium cells are located within arrested phagosomes and a breakdown of hostsymbiont recognition mechanisms under stress might lead to their maturation to phagolysosomes. Antipathogenic responses in mature phagolysosomes involve the generation of ROS and nitric oxide (Wink et al., 2011) and thermal stress-induced production of nitric oxide in symbiotic cnidarians has been associated with the apoptotic-like cell death pathways, that themselves are significant cellular mechanisms of bleaching (Perez and Weis, 2006; Dunn and Weis, 2009; Hawkins et al., 2013). The potential importance of host-produced hydrogen peroxide is highlighted in the current study, where host catalase activity in A. millepora at $33^{\circ} \mathrm{C}$ remained high until the end of the experiment, despite photosynthetic breakdown (and loss of pigment) that might be expected to limit ROS synthesis as a result of lower rates of oxygen evolution and tissue pO2 in advanced bleaching states (Fig. 1; Nii and Muscatine, 1997; Richier et al., 2005). The presence of a high hydrogen peroxide concentration of host origin could also explain the KatG increase and APX inhibition in the symbionts of A. millepora on the final day of observation, since neither was related to changes in symbiont SOD levels. While the specific role of ROS in host immune responses has not been investigated in scleractinian corals, Mydlarz and Harvell (2007) have demonstrated an increased peroxidase activity (measured 
as holobiont response) to a fungal infection in the symbiotic sea fan Gorgonia ventalina.

\section{Conclusions}

The interspecific variability of the coral holobiont to environmental stress is the result of the interplay of many different physiological levels, as well as acclimatory (environmental history) and adaptive processes that modulate the specific stress impact. However, at the basic physiological level, cellular function and the ability to maintain homeostasis (e.g., redox, $\mathrm{pH}, \mathrm{Ca}^{2+}$ ) are essential for the stability of this primarily nutritional symbiotic relationship (Fig. 1). This study shows that, under the thermal and light scenario tested here, no significant changes in enzymatic antioxidant defences occurred in the dinoflagellate symbiont. Host defences increased in the form of enhanced scavenging of hydrogen peroxide, which preceded photosynthetic dysfunction and bleaching in the susceptible corals. These observations illustrate that host redox mechanisms under thermal stress are not always dictated by symbiont photophysiology. On the other hand, they also show that host catalase activity, if viewed as an isolated proxy, may not be protective or predictive of bleaching, even though a connection between ROS scavenging and activation of apoptotic-like pathways was evident in the thermally susceptible coral. This interspecific variability in ROS production-apoptosis regulation (Richier et al., 2006; Tchernov et al., 2011) is worthy of further attention.

Supplementary data to this article can be found online at http://dx. doi.org/10.1016/j.cbpa.2015.08.012.

\section{Acknowledgements}

This work was funded by a Royal Society of New Zealand Marsden Fund grant (contract number VUW0902) to SKD, PLF, SD, OH-G, and WL and supported by a Marsden-funded PhD scholarship to TK, and a Commonwealth Scholarship awarded to TDH. We would like to thank the HIRS staff and in particular Dr. Kyra Hay and Dr. Liz Perkins for logistic support and Dr. Olga Pantos (University of Queensland) for assistance with transportation and storage of coral samples. This manuscript benefited greatly from the helpful comments and suggestions of two anonymous reviewers.

\section{References}

Abrego, D., Ulstrup, K.E., Willis, B.L., van Oppen, M.J.H., 2008. Species-specific interactions between algal endosymbionts and coral hosts define their bleaching response to heat and light stress. Proc. R. Soc. B 275, 2273-2282.

AIMS, 2013. Table generated 25th March 2013 using Reef Monitoring, Heron Island HERFL1 Water Temperature @2 m Heron Island Relay Pole 3 Long term Monitoring and Data Centre, AIMS Viewed 25th March 2013 http://data.aims.gov.au/aimsrtds/ datatool.xhtml.

Asada, K., 1984. Chloroplasts: formation of active oxygen and its scavenging. Methods Enzymol. 105, 422-429.

Asada, K., 1999. The water-water cycle in chloroplasts: scavenging of active oxygens and dissipation of excess photons. Annu. Rev. Plant Physiol. Plant Mol. Biol. 50, 601-639.

Barshis, D.J., Stillman, J.H., Gates, R.D., Toonen, R.J., Smith, L.W., Birkeland, C., 2010. Protein expression and genetic structure of the coral Porites lobata in an environmentally extreme Samoan back reef: does host genotype limit phenotypic plasticity? Mol. Ecol. $19,1705-1720$.

Beauchamp, C., Fridovich, I., 1971. Superoxide dismutase: improved assays and an assay applicable to acrylamide gels. Anal. Biochem. 44, 276-287.

Beers, R., Sizer, I.W., 1952. A spectrophotometric method for measuring the breakdown of hydrogen peroxide by catalase. J. Biol. Chem. 195, 133-140.

Berkelmans, R., Willis, B., 1999. Seasonal and local spatial patterns in the upper thermal limits of corals on the inshore Central Great Barrier Reef. Coral Reefs 18, 219-228.

Brown, B.E., Ambarsari, I., Warner, M.E., Fitt, W.K., Dunne, R.P., Gibb, S.W., Cummings, D.G., 1999. Diurnal changes in photochemical efficiency and xanthophyll concentrations in shallow water reef corals: evidence for photoinhibition and photoprotection. Coral Reefs 19, 99-105.

Brown, B.E., Downs, C.A., Dunne, R.P., Gibb, S.W., 2002a. Exploring the basis of thermotolerance in the reef coral Goniastrea aspera. Mar. Ecol. Prog. Ser. 242, 119-129.

Brown, B.E., Downs, C.A., Dunne, R.P., Gibb, S.W., 2002b. Preliminary evidence for tissue retraction as a factor in photoprotection of corals incapable of xanthophyll cycling. J. Exp. Mar. Biol. Ecol. 277, 129-144.
Downs, C.A., Mueller, E., Phillips, S., Fauth, J.E., Woodley, C.M., 2000. A molecular biomarker system for assessing the health of coral (Montastraea faveolata) during heat stress. Mar. Biotechnol. 2, 533-544.

Downs, C.A., Fauth, J.E., Halas, J.C., Dustan, P., Bemiss, J., Woodley, C.M., 2002. Oxidative stress and seasonal coral bleaching. Free Radic. Biol. Med. 33, 533-543.

Downs, C., McDougall, K.E., Woodley, C.M., Fauth, J.E., Richmond, R.H., Kushmaro, A., Gibb, S.W., Loya, Y., Ostrander, G.K., Kramarsky-Winter, E., 2013. Heat-stress and lightstress induce different cellular pathologies in the symbiotic dinoflagellate during coral bleaching. PLoS ONE 8, e77173.

Dunn, S.R., Weis, V.M., 2009. Apoptosis as a post-phagocytic winnowing mechanism in a coral-dinoflagellate mutualism. Environ. Microbiol. 11, 268-276.

Dunn, S.R., Thomason, J.C., le Tissier, M.D.A., Bythell, J.C., 2004. Heat stress induces different forms of cell death in sea anemones and their endosymbiotic algae depending on temperature and duration. Cell Death Differ. 11, 1213-1222.

Dunn, S.R., Schnitzler, C.E., Weis, V.M., 2007. Apoptosis and autophagy as mechanisms of dinoflagellate symbiont release during cnidarian bleaching: every which way you lose. Proc. R. Soc. B 274, 3079-3085.

Dykens, J.A., Shick, J.M., 1984. Photobiology of the symbiotic sea anemone, Anthopleura elegantissima: defenses against photodynamic effects, and seasonal photoacclimatization. Biol. Bull. 167, 683-697.

Dykens, J.A., Shick, J.M., Benoit, C., Buettner, G.R., Winston, G.W., 1992. Oxygen radical production in the sea anemone Anthopleura elegantissima and its endosymbiotic algae. J. Exp. Biol. 168, 219-241.

Eakin, C.M., Lough, J.M., Heron, S.F., 2009. Climate variability and change: monitoring data and evidence for increased coral bleaching stress. In: van Oppen, M.J.H., Lough, J.M. (Eds.), Coral Bleaching. Springer, Heidelberg, pp. 41-67.

Enríquez, S., Méndez, E.R., Iglesias-Prieto, R., 2005. Multiple scattering on coral skeletons enhances light absorption by symbiotic algae. Limnol. Oceanogr. 50, 1025-1032.

Ferrier-Pagès, C., Richard, C., Forcioli, D., Allemand, D., Pichon, M., Shick, J.M., 2007. Effects of temperature and UV radiation increases on the photosynthetic efficiency in four scleractinian coral species. Biol. Bull. 213, 76-87.

Fisher, P.L., Malme, M.K., Dove, S., 2012. The effect of temperature stress on coral-Symbiodinium associations containing distinct symbiont types. Coral Reefs 31, 473-485.

Fitt, W.K., Brown, B.E., Warner, M.E., Dunne, R.P., 2001. Coral bleaching: interpretation of thermal tolerance limits and thermal thresholds in tropical corals. Coral Reefs 20 51-65.

Fitt, W.K., Gates, R.D., Hoegh-Guldberg, O., Bythell, J.C., Jatkar, A., Grottoli, A.G., Gomez, M., Fisher, P., Lajeunesse, T.C., Pantos, O., Iglesias-Prieto, R., Franklin, D.J., Rodrigues, L.J. Torregiani, J.M., van Woesik, R., Lesser, M.P., 2009. Response of two species of IndoPacific corals, Porites cylindrica and Stylophora pistillata, to short-term thermal stress: the host does matter in determining the tolerance of corals to bleaching. J. Exp. Mar. Biol. Ecol. 373, 102-110.

Franklin, E.C., Stat, M., Pochon, X., Putnam, H.M., Gates, R.D., 2012. GeoSymbio: a hybrid cloud-based web application of global geospatial bioinformatics and ecoinformatics for Symbiodinium-host symbioses. Mol. Ecol. Resour. 12, 369-373.

Fryer, M.J., Andrews, J.R., Oxborough, K., Blowers, D.A., Baker, N.R., 1998. Relationship between $\mathrm{CO}_{2}$ assimilation, photosynthetic electron transport, and active $\mathrm{O}_{2}$ metabolism in leaves of maize in the field during periods of low temperature. Plant Physiol. 116 $571-580$.

Gates, R.D., Baghdasarian, G., Muscatine, L., 1992. Temperature stress causes host cell detachment in symbiotic cnidarians: implications for coral bleaching. Biol. Bull. 182, 324-332.

Gorbunov, M.Y., Kolber, Z.S., Lesser, M.P., Falkowski, P.G., 2001. Photosynthesis and photoprotection in symbiotic corals. Limnol. Oceanogr. 46, 75-85.

Grottoli, A.G., Rodrigues, L.J., Juarez, C., 2004. Lipids and stable carbon isotopes in two species of Hawaiian corals, Porites compressa and Montipora verrucosa, following a bleaching event. Mar. Biol. 145, 621-631.

Grottoli, A.G., Rodrigues, L.J., Palardy, J.E., 2006. Heterotrophic plasticity and resilience in bleached corals. Nature 440, 1186-1189.

Grottoli, A.G., Warner, M.E., Levas, S.J., Aschaffenburg, M.D., Schoepf, V., McGinley, M., Baumann, J., Matsui, Y., 2014. The cumulative impact of annual coral bleaching can turn some coral species winners into losers. Glob. Chang. Biol. 20, 3823-3833.

Halliwell, B., Gutteridge, J.M.C., 2007. Free Radicals in Biology and Medicine. 4th ed. Oxford University Press, Oxford, UK.

Hawkins, T.D., Bradley, B.J., Davy, S.K., 2013. Nitric oxide mediates coral bleaching through an apoptotic-like cell death pathway: evidence from a model sea anemonedinoflagellate symbiosis. FASEB J. 27, 4790-4798.

Hawkins, T.D., Krueger, T., Becker, S., Fisher, P.L., Davy, S.K., 2014. Differential nitric oxide synthesis and host cell apoptosis correlate with bleaching susceptibility in reef corals. Coral Reefs 33, 141-153.

Higuchi, T., Fujimura, H., Arakaki, T., Oomori, T., 2008. Activities of antioxidant enzymes (SOD and CAT) in the coral Galaxea fascicularis against increased hydrogen peroxide concentrations in seawater. Proceedings of the 11th International Coral Reef Symposium, Fort Lauderdale, FL, USA, pp. 926-930 (7-11 July 2008).

Higuchi, T., Fujimura, H., Hitomi, Y., Arakaki, T., Oomori, T., Suzuki, Y., 2010. Photochemical formation of hydroxyl radicals in tissue extracts of the coral Galaxea fascicularis. Photochem. Photobiol. 86, 1421-1426.

Higuchi, T., Suzuki, Y., Fujimura, H., 2012. Multiple effects of hydrogen peroxide and temperature on antioxidants and bleaching. Proceedings of the 12th International Coral Reef Symposium, Cairns, Australia (9-13 July 2012).

Hoegh-Guldberg, O., Jones, R.J., 1999. Photoinhibition and photoprotection in symbiotic dinoflagellates from reef-building corals. Mar. Ecol. Prog. Ser. 183, 73-86.

Iglesias-Prieto, R., Trench, R.K., 1994. Acclimation and adaptation to irradiance in symbiotic dinoflagellates. I. Responses of the photosynthetic unit to changes in photon flux density. Mar. Ecol. Prog. Ser. 113, 163-175. 
Imbs, A., Yakovleva, I., 2012. Dynamics of lipid and fatty acid composition of shallowwater corals under thermal stress: an experimental approach. Coral Reefs 31 , 41-53.

Jones, A., Berkelmans, R., 2010. Potential costs of acclimatization to a warmer climate: growth of a reef coral with heat tolerant vs. sensitive symbiont types. PLoS ONE 5 (e10437).

Jones, R.J., Hoegh-Guldberg, O., Larkum, A.W.D., Schreiber, U., 1998. Temperature-induced bleaching of corals begins with impairment of the $\mathrm{CO}_{2}$ fixation mechanism in zooxanthellae. Plant Cell Environ. 21, 1219-1230.

Krueger, T., Becker, S., Pontasch, S., Dove, S., Hoegh Guldberg, O., Leggat, W., Fisher, P.L., Davy, S.K., 2014. Antioxidant plasticity and thermal sensitivity in four types of Symbiodinium sp. J. Phycol. 50, 1035-1047.

Kuguru, B., Achituv, Y., Gruber, D.F., Tchernov, D., 2010. Photoacclimation mechanisms of corallimorpharians on coral reefs: photosynthetic parameters of zooxanthellae and host cellular responses to variation in irradiance. J. Exp. Mar. Biol. Ecol. 394, 53-62.

Lesser, M.P., 1996. Elevated temperatures and ultraviolet radiation cause oxidative stress and inhibit photosynthesis in symbiotic dinoflagellates. Limnol. Oceanogr. 41, 271-283.

Lesser, M.P., 1997. Oxidative stress causes coral bleaching during exposure to elevated temperatures. Coral Reefs 16, 187-192.

Lesser, M.P., 2006. Oxidative stress in marine environments: biochemistry and physiological ecology. Annu. Rev. Physiol. 68, 253-278.

Lesser, M.P., 2011. Coral bleaching: causes and mechanisms. In: Dubinksy, Z., Stambler, N. (Eds.), Coral Reefs: An Ecosystem in Transition. Springer, Heidelberg, Germany, pp. 405-419.

Lesser, M.P., Farrell, J.H., 2004. Exposure to solar radiation increases damage to both host tissues and algal symbionts of corals during thermal stress. Coral Reefs 23, 367-377.

Lesser, M.P., Shick, J.M., 1989a. Effects of irradiance and ultraviolet radiation on photoadaptation in the zooxanthellae of Aiptasia pallida: primary production, photoinhibition, and enzymic defenses against oxygen toxicity. Mar. Biol. 102, 243-255.

Lesser, M.P., Shick, J.M., 1989b. Photoadaption and defenses against oxygen toxicity in zooxanthellae from natural populations of symbiotic cnidarians. J. Exp. Mar. Biol. Ecol. $134,129-141$

Lesser, M.P., Stochaj, W.R., Tapley, D.W., Shick, J.M., 1990. Bleaching in coral reef anthozoans: effects of irradiance, ultraviolet radiation, and temperature on the activities of protective enzymes against active oxygen. Coral Reefs 8, 225-232.

Levy, O., Achituv, Y., Yacobi, Y.Z., Stambler, N., Dubinsky, Z., 2006. The impact of spectral composition and light periodicity on the activity of two antioxidant enzymes (SOD and CAT) in the coral Favia favus. J. Exp. Mar. Biol. Ecol. 328, 35-46.

Liñán-Cabello, M.A., Flores-Ramírez, L.A., Zenteno-Savin, T., Olguín-Monroy, N.O., SosaAvalos, R., Patiño-Barragan, M., Olivos-Ortiz, A., 2010. Seasonal changes of antioxidant and oxidative parameters in the coral Pocillopora capitata on the Pacific coast of Mexico. Mar. Ecol. 31, 407-417.

Logan, D.D.K., LaFlamme, A.C., Weis, V.M., Davy, S.K., 2010. Flow-cytometric characterization of the cell-surface glycans of symbiotic dinoflagellates (Symbiodinium spp.) J. Phycol. 46, 525-533.

Loya, Y., Sakai, K., Yamazato, K., Nakano, Y., Sambali, H., van Woesik, R., 2001. Coral bleaching: the winners and the losers. Ecol. Lett. 4, 122-131.

Maxwell, K., Johnson, G.N., 2000. Chlorophyll fluorescence-a practical guide. J. Exp. Bot. 51, 659-668.

McGinty, E.S., Pieczonka, J., Mydlarz, L.D., 2012. Variations in reactive oxygen release and antioxidant activity in multiple Symbiodinium types in response to elevated temperature Microb. Ecol. 64, 1000-1007.

McWilliams, J.P., Côté, I.M., Gill, J.A., Sutherland, W.J., Watkinson, A.R., 2005. Accelerating impacts of temperature-induced coral bleaching in the Caribbean. Ecology 86, 2055-2060.

Middlebrook, R., Hoegh-Guldberg, O., Leggat, W., 2008. The effect of thermal history on the susceptibility of reef-building corals to thermal stress. J. Exp. Biol. 211, 1050-1056.

Middlebrook, R., Anthony, K.R., Hoegh-Guldberg, O., Dove, S., 2010. Heating rate and symbiont productivity are key factors determining thermal stress in the reef-building coral Acropora formosa. J. Exp. Biol. 213, 1026-1034.

Muscatine, L., Porter, J.W.., 1977. Reef corals: mutualistic symbioses adapted to nutrientpoor environments. Bioscience 27, 454-460.

Mydlarz, L.D., Harvell, C.D., 2007. Peroxidase activity and inducibility in the sea fan cora exposed to a fungal pathogen. Comp. Biochem. Physiol. A Mol. Integr. Physiol. 146, $54-62$

Mydlarz, L.D., Jacobs, R.S., 2004. Comparison of an inducible oxidative burst in free-living and symbiotic dinoflagellates reveals properties of the pseudopterosins. Phytochemistry $65,3231-3241$

Nakano, Y., Asada, K., 1981. Hydrogen peroxide is scavenged by ascorbate-specific peroxidase in spinach chloroplasts. Plant Cell Physiol. 22, 867-880.

Nii, C.M., Muscatine, L., 1997. Oxidative stress in the symbiotic sea anemone Aiptasia pulchella (Carlgren, 1943): contribution of the animal to superoxide ion production at elevated temperature. Biol. Bull. 192, 444-456.

Palenik, B., Morel, F.M., 1990. Comparison of cell-surface L-amino acid oxidases from several marine phytoplankton. Mar. Ecol. Prog. Ser. 59, 195-201.

Pandolfi, J.M., Bradbury, R.H., Sala, E., Hughes, T.P., Bjorndal, K.A., Cooke, R.G., McArdle, D. McClenachan, L., Newman, M.J.H., Paredes, G., 2003. Global trajectories of the longterm decline of coral reef ecosystems. Science 301, 955-958.

Paxton, C.W., Davy, S.K., Weis, V.M., 2013. Stress and death of cnidarian host cells play a role in cnidarian bleaching. J. Exp. Biol. 216, 2813-2820.
Perez, S., Weis, V.M., 2006. Nitric oxide and cnidarian bleaching: an eviction notice mediates breakdown of a symbiosis. J. Exp. Biol. 209, 2804-2810.

Porra, R., Thompson, W., Kriedemann, P., 1989. Determination of accurate extinction coefficients and simultaneous equations for assaying chlorophylls $a$ and $b$ extracted with four different solvents: verification of the concentration of chlorophyll standards by atomic absorption spectroscopy. Biochim. Biophys. Acta 975, 384-394.

Ralph, P.J., Gademann, R., Larkum, A.W.D., 2001. Zooxanthellae expelled from bleached corals at $33{ }^{\circ} \mathrm{C}$ are photosynthetically competent. Mar. Ecol. Prog. Ser. 220, 163-168.

Richier, S., Furla, P., Plantivaux, A., Merle, P.-L., Allemand, D., 2005. Symbiosis-induced adaptation to oxidative stress. J. Exp. Biol. 208, 277-285.

Richier, S., Sabourault, C., Courtiade, J., Zucchini, N., Allemand, D., Furla, P., 2006. Oxidative stress and apoptotic events during thermal stress in the symbiotic sea anemone, Anemonia viridis. FEBS J. 273, 4186-4198.

Roberty, S., Fransolet, D., Cardol, P., Plumier, J.-C., Franck, F., 2015. Imbalance between oxygen photoreduction and antioxidant capacities in Symbiodinium cells exposed to combined heat and high light stress. Coral Reefs. http://dx.doi.org/10.1007/s00338015-1328-5.

Rowan, R., 2004. Coral bleaching: thermal adaptation in reef coral symbionts. Nature 430, 742-742.

Rowan, R., Knowlton, N., Baker, A., Jara, J., 1997. Landscape ecology of algal symbionts creates variation in episodes of coral bleaching. Nature 388, 265-269.

Sammarco, P.W., Winter, A., Stewart, J.C., 2006. Coefficient of variation of sea surface temperature (SST) as an indicator of coral bleaching. Mar. Biol. 149, 1337-1344.

Sampayo, E.M., Ridgway, T., Bongaerts, P., Hoegh-Guldberg, O., 2008. Bleaching susceptibility and mortality of corals are determined by fine-scale differences in symbiont type. Proc. Natl. Acad. Sci. U. S. A. 105, 10444-10449.

Sandeman, I.M., 2006. Fragmentation of the gastrodermis and detachment of zooxanthellae in symbiotic cnidarians: a role for hydrogen peroxide and $\mathrm{Ca}^{2+}$ in coral bleaching and algal density control. Rev. Biol. Trop. 54, 79-96.

Saragosti, E., Tchernov, D., Katsir, A., Shaked, Y., 2010. Extracellular production and degradation of superoxide in the coral Stylophora pistillata and cultured Symbiodinium. PLOS ONE 5, e12508.

Shick, J.M., Dykens, J.A., 1985. Oxygen detoxification in algal-invertebrate symbiosis from the Great Barrier Reef. Oecologia 66, 33-41.

Shick, J.M., Lesser, M.P., Dunlap, W.C., Stochaj, W.R., Chalker, B.E., Wu, Won, J., 1995. Depth-dependent responses to solar ultraviolet radiation and oxidative stress in the zooxanthellae coral Acropora microphthalma. Mar. Biol. 122, 41-51.

Smith-Keune, C., van Oppen, M., 2006. Genetic structure of a reef-building coral from thermally distinct environments on the Great Barrier Reef. Coral Reefs 25, 493-502.

Stimson, J., Kinzie, R.A., 1991. The temporal pattern and rate of release of zooxanthellae from the reef coral Pocillopora damicornis (Linnaeus) under nitrogen-enrichment and control conditions. J. Exp. Mar. Biol. Ecol. 153, 63-74.

Stimson, J., Sakai, K., Sembali, H., 2002. Interspecific comparison of the symbiotic relationship in corals with high and low rates of bleaching-induced mortality. Coral Reefs 21 , 409-421.

Suggett, D.J., Warner, M.E., Smith, D.J., Davey, P., Hennige, S., Baker, N.R., 2008. Photosynthesis and production of hydrogen peroxide by Symbiodinium (Pyrrhophyta) phylotypes with different thermal tolerances. J. Phycol. 44, 948-956.

Tchernov, D., Kvitt, H., Haramaty, L., Bibby, T.S., Gorbunov, M.Y., Rosenfeld, H., Falkowski, P.G., 2011. Apoptosis and the selective survival of host animals following thermal bleaching in zooxanthellate corals. Proc. Natl. Acad. Sci. U. S. A. 108, 9905-9909.

Teixeira, T., Diniz, M., Calado, R., Rosa, R., 2013. Coral physiological adaptations to air exposure: Heat shock and oxidative stress responses in Veretillum cynomorium. J. Exp. Mar. Biol. Ecol. 439, 35-41.

Ulstrup, K.E., Van Oppen, M., Kühl, M., Ralph, P.J., 2007. Inter-polyp genetic and physiological characterisation of Symbiodinium in an Acropora valida colony. Mar. Biol. 153, 225-234.

Venn, A.A., Wilson, M.A., Trapido-Rosenthal, H.G., Keely, B.J., Douglas, A.E., 2006. The impact of coral bleaching on the pigment profile of the symbiotic algae, Symbiodinium. Plant Cell Environ. 29, 2133-2142.

Wakefield, T.S., Farmer, M.A., Kempf, S.C., 2000. Revised description of the fine structure of in situ“Zooxanthelllae" genus Symbiodinium. Biol. Bull. 199, 76-84.

Warner, M.E., Fitt, W.K., Schmidt, G.W., 1999. Damage to photosystem II in symbiotic dinoflagellates: a determinant of coral bleaching. Proc. Natl. Acad. Sci. U. S. A. 96, 8007-8012.

Weis, V.M., 2008. Cellular mechanisms of cnidarian bleaching: stress causes the collapse of symbiosis. J. Exp. Biol. 211, 3059-3066.

Wink, D.A., Hines, H.B., Cheng, R.Y., Switzer, C.H., Flores-Santana, W., Vitek, M.P., Ridnour, L.A., Colton, C.A., 2011. Nitric oxide and redox mechanisms in the immune response. J. Leukoc. Biol. 89, 873-891.

Winterbourn, C.C., 2008. Reconciling the chemistry and biology of reactive oxygen species. Nat. Chem. Biol. 4, 278-286.

Yakovleva, I., Bhagooli, R., Takemura, A., Hidaka, M., 2004. Differential susceptibility to oxidative stress of two scleractinian corals: antioxidant functioning of mycrosporineglycine. Comp. Biochem. Physiol. B: Biochem. Mol. Biol. 139, 721-730.

Yakovleva, I.M., Baird, A.H., Yamamoto, H.H., Bhagooli, R., Nonaka, M., Hidaka, M., 2009. Algal symbionts increase oxidative damage and death in coral larvae at high temperatures. Mar. Ecol. Prog. Ser. 378, 105-112.

Zor, T., Selinger, Z., 1996. Linearization of the Bradford protein assay increases its sensitivity: theoretical and experimental studies. Anal. Biochem. 236, 302-308. 